\title{
Kalça ekleminde fizik muayene ve radyolojik değerlendirme
}

\section{Physical examination and radiological evaluation of the hip joint}

\author{
Melih Güven¹, Budak Akman², Burak Çağrı Aksu \\ 1Yeditepe Üniversitesi Tıp Fakültesi, Ortopedi ve Travmatoloji Anabilim Dalı, İstanbul, Türkiye \\ 2Özel Gisbir Hastanesi, Ortopedi ve Travmatoloji Kliniği, İstanbul, Türkiye
}

\begin{abstract}
Genç erişkin ve erişkin hastalarda kalça ağrısı, eklem içi ve eklem dışı patolojilerden kaynaklanabilir. Kalça ağrısında ayırıcı tanı yelpazesi oldukça geniştir. Doğru tanı koyabilmek için detaylı bir klinik öykü sorgusu yapmak, fizik muayene yöntemleri ve görüntüleme tetkiklerini sistematik bir şekilde kullanmak gereklidir. Kalça eklemine yönelik birçok spesifik fizik muayene yöntemi tarif edilmiştir. Bu derlemede fizik muayene yöntemleri sistematik bir şekilde ele alınmış ve ardından düz radyografik değerlendirmede sıklıkla kullanılan görüntüleme tetkikleri ve değerlendirme yöntemleri tanımlanmıştır.
\end{abstract}

Anahtar sözcükler: kalça eklemi; kalça ağrısı; fizik muayene; radyolojik değerlendirme
Hip pain in young adult and adult patients can be based on intraarticular and extraarticular hip joint pathologies. The spectrum of differential diagnosis in the hip pain is quite wide. Detailed query of the clinical history, systematical evaluation of physical examination methods and imaging modalities are essential for the correct diagnosis. There are a lot of specific physical examination methods which have been described for the hip joint. In this review, physical examination methods have been discussed in a systematic manner and plain radiographic evaluation and assessment methods which are commonly used in clinical practice have been described.

Key words: hip joint; hip pain; physical examination; radiological evaluation

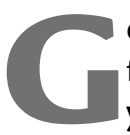
enç erişkin ve erişkin hastalarda kalça eklemi fizik muayenesi, kemik, bağ ve kas-tendon yapılarının ayrıntılı değerlendirmesini içerir. Hekim hastasının statik (denge) ve dinamik (fonksiyonel) aktivitelerini göz önünde bulundurup, kalça eklemini oluşturan kemiksel ve yumuşak doku yapıları arasındaki etkileşimleri anlamalı ve fizik muayene ile bu ilişkileri ortaya koyabilmelidir. Kalça eklemine ait patolojilerde, sıklıkla kalça ekleminin önünde kasık bölgesinde ağrı tanımlansa da, kalça lateralinde ve arkasında da ağrılar olabilmektedir. Ayrıca, kalça eklemi dışındaki bir takım patolojiler de bu bölgelerde ağrıya yol açabilir.

Kalça ağrısı ile hekime başvuran hastaların ilk değerlendirmesinde, özellikle eklem içi patolojilerin \%60 oranında tanımlanamadığı bildirilmektedir. ${ }^{[1]}$ Burnett ve arkadaşlarının ${ }^{[2]}$ bir çalışmasında ise kalça ağrısı tarif edilen femoroasetabular sıkışma (FAS) sendromlu hastalarda, semptomların başlangıcından kesin tanı koyulmasına kadar geçen sürenin ortalama 21 ay olabildiği, kesin tanı koyulana ve tedavi uygulanana kadar hastaların ortalama üç hekim tarafından değerlendirilmek zorunda kaldıkları vurgulanmıştır.

Kalça eklemine yönelik fizik muayene yöntemleri oldukça ayrıntılıdır ve birçok spesifik test tanımlanmıştır. Ancak, Martin ve arkadaşları, ${ }^{[3]}$ özellikle kalça sorunları ile ilgilenen ortopedistler arasında yapmış oldukları bir çalışmada, ortopedistlerin kullandıkları fizik muayene yöntemlerinin; supin pozisyonda kalça fleksiyonu, kalça iç ve dış rotasyonu, supin pozisyonda pasif kalça rotasyonu, FABER ve FADIR testleri, dirence karşı düz bacak kaldırma testi, Trendelenburg testi ve femoral anteversiyon değerlendirmesi ile sınırlı kaldığını bildirmişlerdir. Bu nedenle de, klinik pratikte, ortopedistlerin ayırıcı tanı yelpazesi oldukça geniş olan kalça eklem patolojilerinde görüntüleme yöntemlerine sıkı sıkıya bağlı kalma zorunlulukları gündeme gelmektedir.

- İletişim adresi: Doç. Dr. Melih Güven, Yeditepe Üniversitesi Tıp Fakültesi, Ortopedi ve Travmatoloji Anabilim Dalı, İstanbul, Türkiye Tel: 0505 - 3737416 e-posta: maguven2000@gmail.com

- Geliș tarihi: 23 Ocak 2015 Kabul tarihi: 23 Ocak 2015 
Tablo 1. Kalça ağrısı nedenleri

\begin{tabular}{|c|c|c|c|}
\hline Anterior kalça ağrısı & Lateral kalça ağrısı & Posterior kalça ağrısı & Diğer nedenler \\
\hline $\begin{array}{l}\text { - Kas straini } \\
\text { - Kontüzyon } \\
\text { - Avulsiyonlar ya da apofizyonel } \\
\text { - } \text { Karalanmalar } \\
\text { - sab̧a dislokasyonu/ } \\
\text { - Asetabular labral yırtıklar ve } \\
\text { serbest cisimler } \\
\text { - Osteitis pubis } \\
\text { - Iliopsoas bursiti/tendiniti } \\
\text { - Stres sendromu } \\
\text { - Femur başı epifiz kayması (FBEK) } \\
\text { - Leg-Calvé-Perthes hastalığı } \\
\text { - Gelişimsel kalça displazisi (GKD) } \\
\text { - Osteoartrit } \\
\text { - Inflamatuvar artrit } \\
\text { - Avasküler nekroz } \\
\text { - Femoroasetabular sıkışma (FAS) }\end{array}$ & $\begin{array}{l}\text { - Trokanterik bursit } \\
\text { - Gluteus medius/minimus } \\
\text { yırtıkları } \\
\text { - iliotibial bant sendromu } \\
\text { - Meraljia parestetika }\end{array}$ & $\begin{array}{l}\text { - Lomber omurga patolojileri } \\
\text { - Kompresif nöropatiler } \\
\text { - Piriformis sendromu } \\
\text { - Sakroiliak eklem patolojileri }\end{array}$ & $\begin{array}{l}\text { - Abdominal/spor hernileri } \\
\text { - Atletik pubalji } \\
\text { - Inguinal herni } \\
\text { - Apandisit } \\
\text { - Jinekolojik (ovarian kist, } \\
\text { pelvik inflamatuvar hastalık, } \\
\text { hamilelik) } \\
\text { - Ürolojik (testiküler, skrotal) } \\
\text { - Genitoüriner (böbrek taşı, } \\
\text { nefrit) } \\
\text { - Psikojenik }\end{array}$ \\
\hline
\end{tabular}

Kalça ağrısı nedenleri, hastanın ağrıyı tarif ettiği bölgeler göz önünde bulundurularak, anterior, lateral ve posterior kalça ağrısı şeklinde sınıflandırılabilir. Ayrıca, koksofemoral eklem dışında başka sistem patolojilerinde de kalça ağrısı yakınması olabilir (Tablo 1). Kalça ekleminde ağrı nedeni olabilecek çok sayıda patoloji arasında ayırıcı tanı yapabilmek için, hastanın değerlendirilmesine öncelikle iyi bir klinik öykü sorgusuyla başlanmalı, ardından klinik öyküdeki mevcut pozitif bulgular üzerinden, sistematik bir fizik muayene ile ayırıcı tanı yelpazesi daraltılmaya çalışılmalıdır. Klinik öykü sorgusu ve fizik muayene ardından, radyografik değerlendirme ile tanıya yönelmek hata yapma ihtimalini de en aza indirecektir.

\section{KLINIK ÖYKÜ SORGUSU}

Kalça ağrısı tanımlanan hastada fizik muayeneye başlamadan önce mutlaka ayrıntılı klinik öykü sorgulaması yapılmalıdır. Hastanın ağrı ile birlikte şikâyetlerinin ve semptomlarının tanımını yapması istenmelidir. Semptomların süresi, devamlı ya da aralıklı olup olmadıkları sorgulanmalıdır. Ortaya çıkış şekli, lokalizasyonu, şikayetlerin spesifik hareket ya da işlerle ilişkisi, kalça ağrısının ana semptom olup olmadığı, mekanik semptomların varlığı, şikayetler nedeniyle fiziksel ya da gündelik aktivitelerin etkilenip etkilenmediği sorgulanmalıdır.

Klinik öykü sorgusunda hastanın ağrısının kalça eklemine ait olduğuna ilişkin ipuçları yakalanabilir. Kalça eklemine ilişkin patolojilerde mutlaka önemli ya da belirgin bir travma öyküsü olmak zorunda değildir. Kalça eklemine ait eklem içi ya da eklem dışı mekanik semptomlar mutlaka sorgulanmalıdır. Bunlar keskin, bıçak saplanır tarzda ve aralıklı ağrı varlığı ile takılma ve atlama hissidir. Kalça eklemine ait patolojilerde, özellikle mekanik sorunlarda, semptomların aktivite ile kötüleşmesi beklenir. Semptomlar, düz plandaki aktivitelerden daha çok rotasyonel planlı aktivitelerde kendini daha fazla ortaya çıkarmaktadır. Özellikle oturma pozisyonunda şikâyetlerin belirginleşmesi, oturur pozisyondan ayağa kalkma sırasında ağıının artması, merdiven inip çıkmada ve yokuş yukarı/aşağı yürümede ağrının alevlenmesi, otomobile ve toplu taşıma araçlarına binip inme gibi aktivitelerde zorlanma, ayakkabı ve çorap giymede güçlük ön planda tanımlanan sıkıntılar arasındadır.

Klinik öykü sorgusunda, daha önce geçirilmiş travmalar ve alt ekstremite cerrahileri, çocukluk ve ergen dönem kalça hastalıkları, ipsilateral diz problemleri, inflamatuvar artrit öyküsü, osteonekroz risk etmenleri, sosyal alışkanlıklar ve sportif $f$ aktiviteler de sorgulanmalıdır.

\section{KALÇA EKLEMi FiZiK MUAYENESi}

Kalça eklemi fizik muayenesinde, ağrıya yol açabilecek kalça eklemine ilişkin eklem içi ve eklem dışı patolojiler öncelikle değerlendirilmelidir. Ancak bunların dışında, pubik ağrıya yol açabilecek nedenler, mevcut alt ekstremite kas spastisiteleri ve kontraktürleri, ilişkili komşu eklemlerin durumu, nörolojik tablo ve kişinin yürüyüş özellikleri de incelenmelidir. 
Kalça eklemine ait fizik muayene yöntemleri; inspeksiyon, palpasyon, eklem hareket genişliği, kas gücü ve spesifik kalça eklem muayeneleri ile nörolojik muayene gibi alt başlıklar halinde incelenebilir. Ancak, bu yazıda daha sistematik bir yaklaşım sunabilmek amacıyla, kalça eklemine ait dört ana tabaka göz önünde bulundurularak, uygulanacak sistematik bir muayene şeması aktarılmaya çalışılacaktır. Bu algoritmada amaç, kalça ekleminin dört ana tabakasını (osteokondral, kapsülolabral, müskülotendinöz ve nörovasküler) ayrıntılı bir şekilde değerlendirmektir. ${ }^{[4]}$

Bu değerlendirmeler yapılırken, ağrının kalça eklemi dışı patolojilerden kaynaklanıp kaynaklanmadığının belirlenmesi gerekir. Hastalar, periartiküler kalça problemleri ve kalça dışı omurga sorunları nedeniyle de değerlendirilmelidir. Ayrıca, periartiküler kalça patolojilerinin birçoğunun eklem içi patolojilerle birliktelik gösterebileceği de unutulmamalıdır.

Yazının ilerleyen bölümlerinde, yürümenin değerlendirilmesi, ayakta, otururken ve yatarken (supin, lateral dekübit ve prone pozisyonlarda) muayene sıralamasıyla, sistematik fizik muayene ayrıntılandırılmaya çalışılacaktır.

\section{YÜRÜMENIN DEĞERLENDIRILMESi}

Hastanın fizik muayenesine, yürümenin gözlemsel olarak değerlendirilmesi ile başlanmalıdır. Hasta, düz bir zemin üzerinde en az 6-8 çift adım uzunluğunca yürütülmeli ve bu esnada, ayak dizilimi ve pozisyonu (kalça anteversiyon artışı, varus-valgus diz, ayak bileği osteoartriti, düztabanlık vb.), diz pozisyonu (varusvalgus dizilim, diz hiperlaksitesi, diz eklem kontraktürleri, ekstremite uzunluk eşitsizliği vb.), pelvik hareketlilik (kalça ankilozu, pelvik tilt ve lomber hiperlordoz, instabilite vb.) ve eksternal destek kullanımı açısından gözlenmelidir.

Kalça eklem patolojilerinde birçok farklı yürüme tipi gözlenebilse de, özellikle iki ana yürüme patolojisi ön planda ortaya çıkmaktadır. Bunlardan ilki antaljik yürümedir. Ağrı nedeniyle basma fazının kısalması sonucu ortaya çıkan bu yürüme şekli, geçirilmiş yakın zamana ait travmalar (kas gerinimi, subluksasyon/dislokasyon, apofizyonel travmalar vb.) ya da kronik ağıı (ileri dejeneratif kalça osteoartriti, avasküler nekroz vb.) nedeniyle ortaya çıkabilir. Diğer sık rastlanan yürüme anomalisi ise Trendelenburg yürüyüşüdür. Yürümenin tek ayak destek fazında, vücut ağırlığının yere basan ekstremite tarafına doğru devrilmesi ve karşı kalçanın düşüşü, abduktor kas yetmezliğine ikincil olarak ortaya çıkan bir yürüme patolojisidir.

Bu iki ana yürüme patolojisi dışında, alt ekstremite kas spastisiteleri ya da kontraktürleri sonucu gözlenebilecek oraklama ya da makaslama yürüyüşleri, bükük diz ya da sert diz yürüyüşleri, parmak ucu ya da ekin yürüyüşleri gibi farklı yürüme biçimleri de göze çarpabilir.

\section{AYAKTA FIZIK MUAYENE}

Yürümenin ardından, hastanın muayenesine ayakta iken devam edilmelidir. Öncelikle inspeksiyonla, pelvik simetri, spina iliaka anterior superior (SiAS) ve spina iliaka posterior superior (SIPS) noktalarına her iki elin başparmakları yerleştirilerek, pelvisin yer düzlemi ile olan ilişkisi gözlenecek şekilde değerlendirilir. Ayrıca, lomber lordoz, servikotorakolomber omurga dizilimi de gözlenmelidir (Şekil 1). Ardından, palpasyonla pelvik bölgede ağrılı olabilecek kas origo ve insersiyoları palpe edilmeli ve ağrılı noktalar kaydedilmelidir. Pelviste palpe edilebilecek temel kemiksel noktalar, SiAS, SiPS, iliak krest, sakroiliak eklemler, lomber omurgadaki spinöz çıııntılar, simfizis pubis, trokanter majör ve tüber iskiadikumdur.

Kalça patolojilerinde tipik olarak kasık ön ağrısı olur; zaman zaman da bu ağrı uyluk anteromediyalinden dizin iç yüzüne doğru yayılır. Ancak, kalça patolojileri için ağrının başladığı noktalar sorgulanırken, "C bulgusu" olarak ifade edilen bir muayene yönteminden yararlanılabilir (Şekil 2). Birinci ve ikinci parmaklar trokanter majörün üstünden açılarak, uyluk anterior-posterior hizasında yerleştirilir ve hastaya kalça ağrısının iki parmak arasında lokalize olup olmadığı sorulur..$^{[5]}$ Buna hasta lateral dekübit pozisyonda yatarken de bakılabilir. Tabii ki, ağı lokalizasyonu posteriora ve posterosuperiora kaydıkça, ağrı kaynağının kalça mı yoksa lomber bölge mi olduğunun ayırdı yapılmalıdır.

Trendelenburg testi, ayakta yapılacak en temel ve spesifik muayene yöntemidir; kalçada abduktor adale gücünü (özellikle gluteus mediusu) değerlendiren bir testtir. Tek bacak basma fazı testi olarak da isimlendirilebilir. Muayene edilecek olan alt ekstremite yerle temas ederken, karşı alt ekstremite diz fleksiyona getirilerek yerden havalandırılır. Eğer yere basan alt ekstremitedeki abduktor adaleler zayıf ise, yaklaşık $10 \mathrm{~s}$ içerisinde pelvis yere basmayan ekstremite tarafina doğru düşecektir (Şekil 3). Bu bulgu 10-20 s arasında gözlenirse, geç Trendelenburg testi pozitifliğinden bahsedilebilir. 20 s üzerinde ise, yorgunluğa bağlı olarak ve yer çekimi etkisi ile birçok kişide pelvis yüksekliğini kaybeder. Yorgunluk nedeniyle gözlenebilen bu durumda test negatif kabul edilmelidir.

Hasta, oturur ve yatar pozisyona alınmadan önce, eklem laksitesi açısından da değerlendirilmelidir. Hipermobilite testleri olarak da isimlendirilen testlere (1. parmak ön kol volar yüzü ilişkisi, 2. ve 5. parmak 

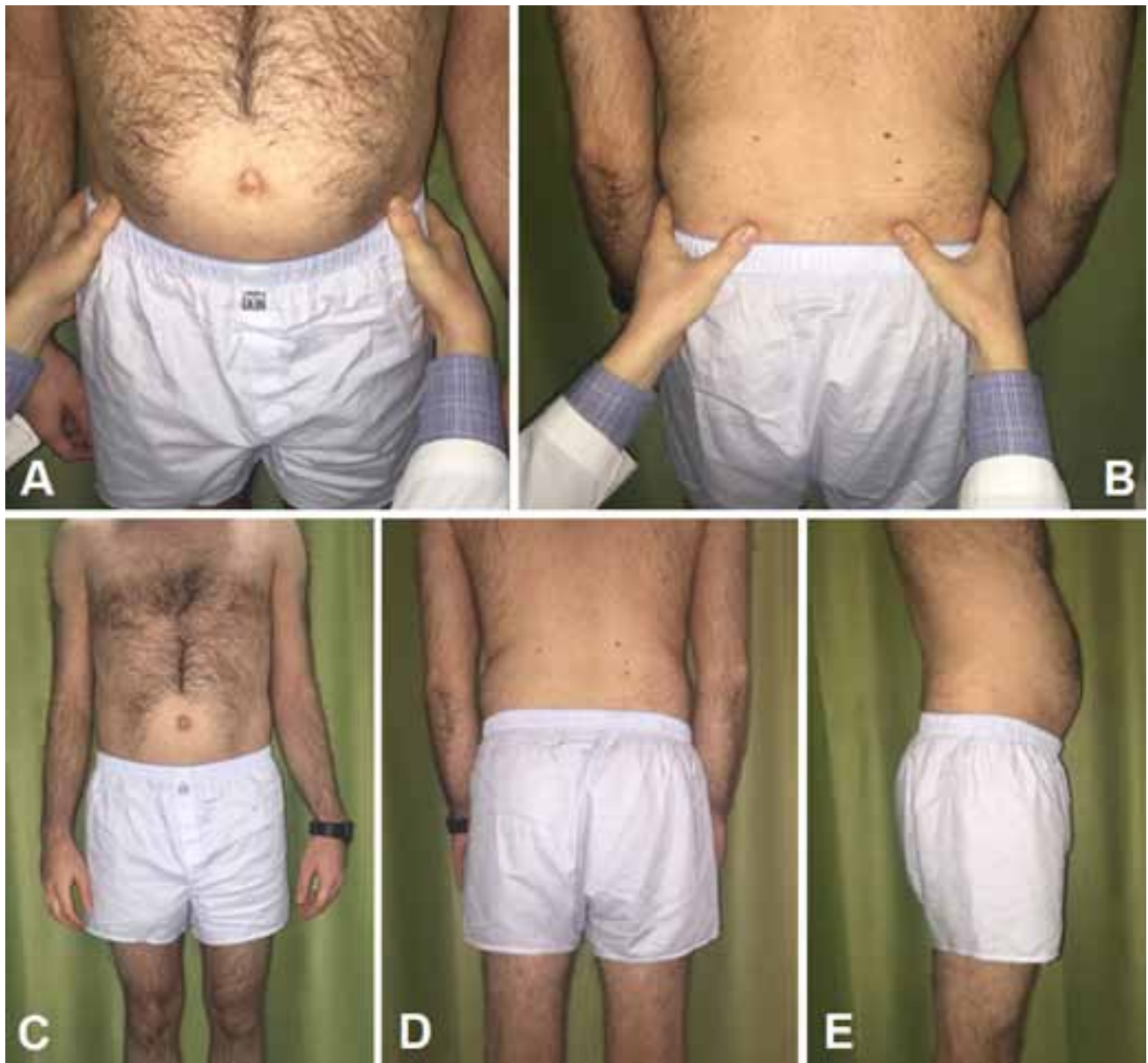

Şekil 1. A-E. Başparmakların SiAS ve SiPS'ye yerleştirilerek pelvisin yer düzlemi ile ilişkisinin değerlendirilmesi (A, B). Torakolomber omurga diziliminin önden ve arkadan, lomber lordozun yandan gözlenmesi (C-E).

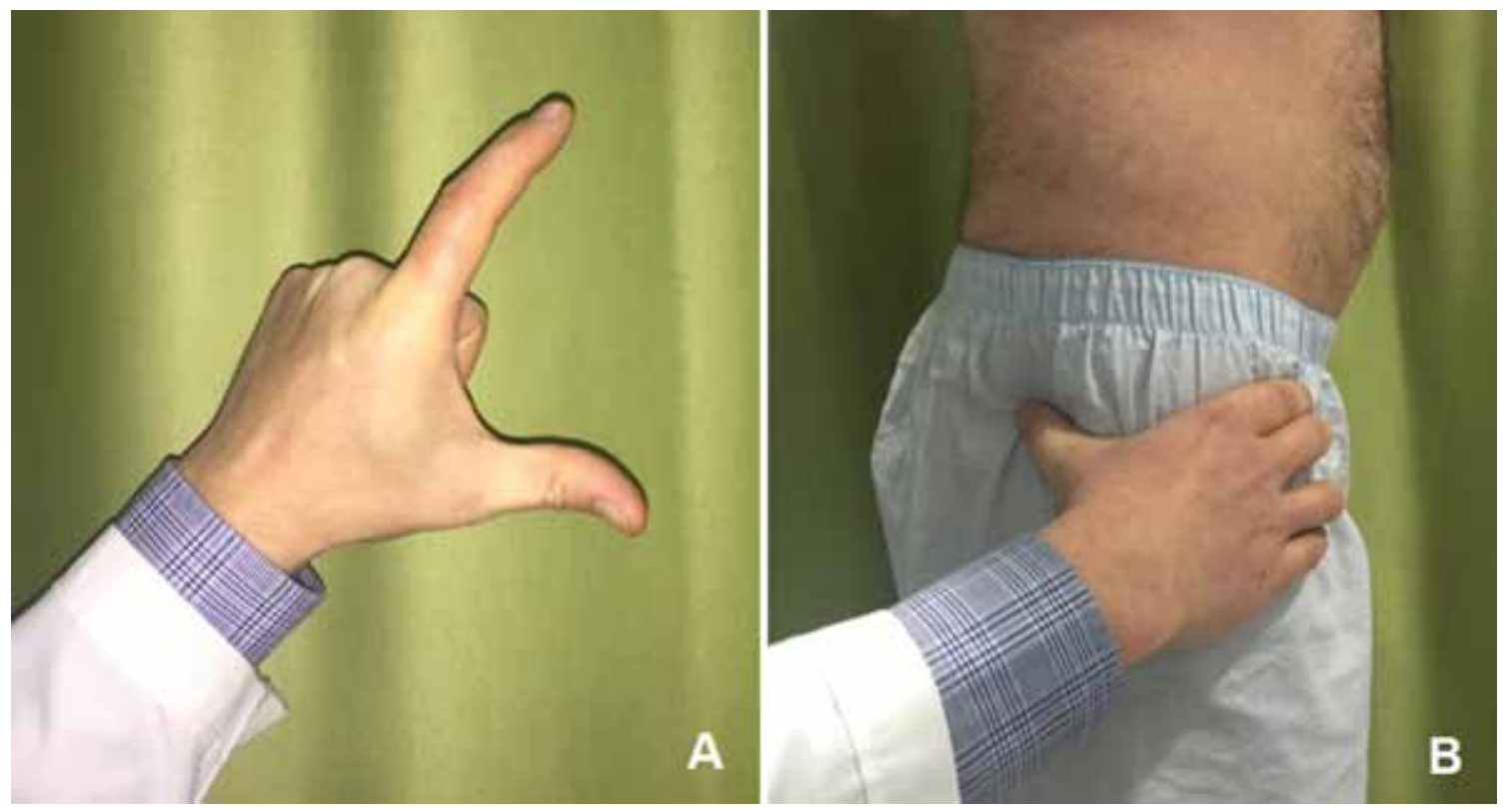

Şekil 2. A, B. Kalça ağrılarında "C bulgusu" (A). Birinci ve ikinci parmağın trokanter majör üstünde anteriorposterior hizada "C" şeklinde yerleştirilmesi (B). 

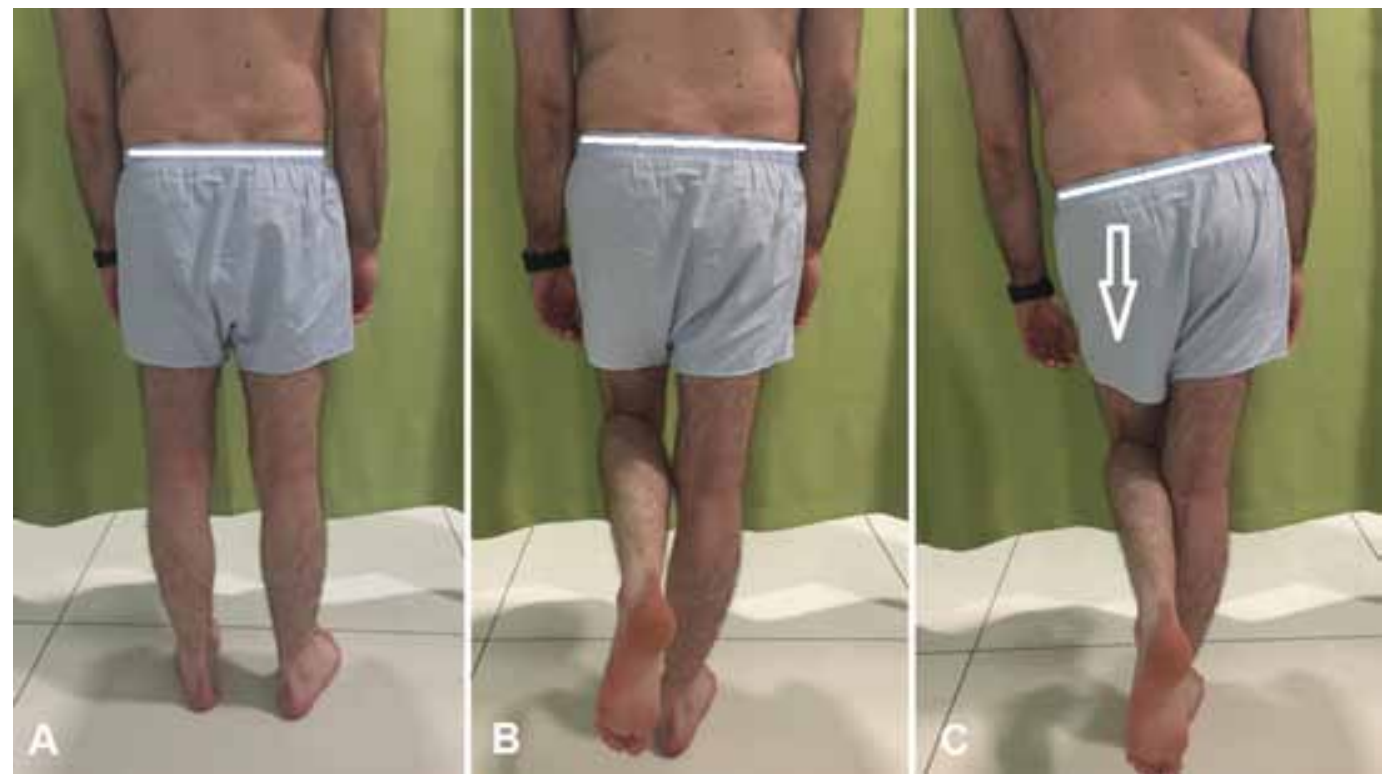

Şekil 3. A-C. Her iki alt ekstremite yerle temas halinde iken pelvis simetrisi (A). Trendelenburg testi negatifliği (B). Trendelenburg testi pozitifliği (C).
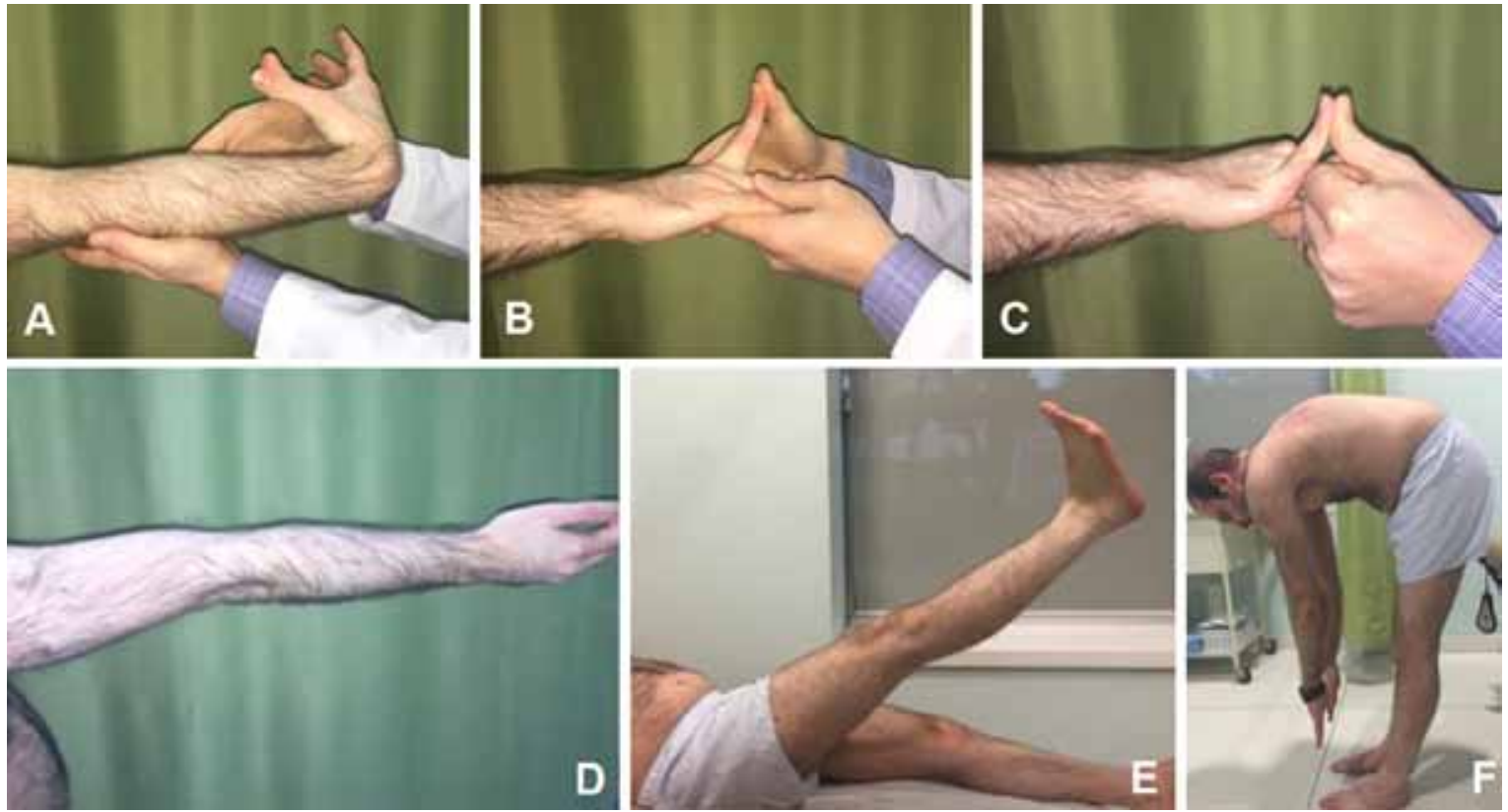

Şekil 4. A-F. Hipermobilite testleri. Birinci parmak - ön kol volar yüz ilişkisi (A). İkinci parmak metakarpofalangeal eklemde ekstansiyon (B), beşinci parmak metakarpofalangeal eklemde ekstansiyon (C), dirsek ekstansiyonu (D), diz ekstansiyonu (E), diz ekstansiyonda iken bel ve kalça fleksiyonu ile parmakların yer ile ilişkisi (F).

metakarpofalangeal eklemde $90^{\circ}$ 'den fazla hiperekstansiyon, $10^{\circ}$ 'den fazla dirsek hiperekstansiyonu, $10^{\circ}$ 'den fazla diz hiperekstansiyonu, diz tam ekstansiyonda iken bel ve kalça fleksiyonu ile parmakların yere değmesi) bakılarak eklem laksitesi hakkında fikir sahibi olunabilir (Şekil 4). Bu testlerden üçünün pozitifliği,kişinin hiperlaksitesi olduğunu gösterir.

\section{OTURURKEN FIZIK MUAYENE}

Ayakta muayenenin ardından hasta oturtulur ve öncelikle kalça eklemine ilişkin rotasyonlar değerlendirilir. Oturur pozisyonda, kalça ve diz eklemleri $90^{\circ}$ fleksiyonda iken, kalça ekleminin simetrik olarak iç ve dış rotasyonuna bakılır (Şekil 5). Bu muayenedeki değerler, 


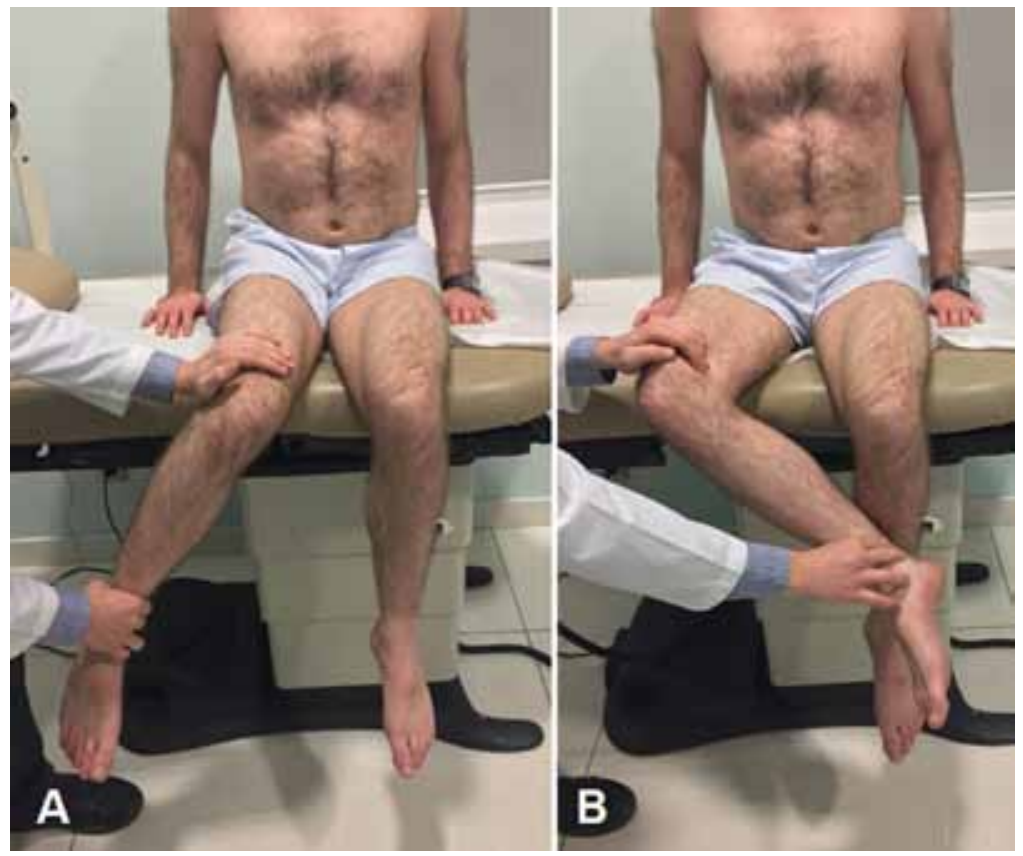

Şekil 5. Oturur pozisyonda kalça iç (A) ve dış (B) rotasyonları.

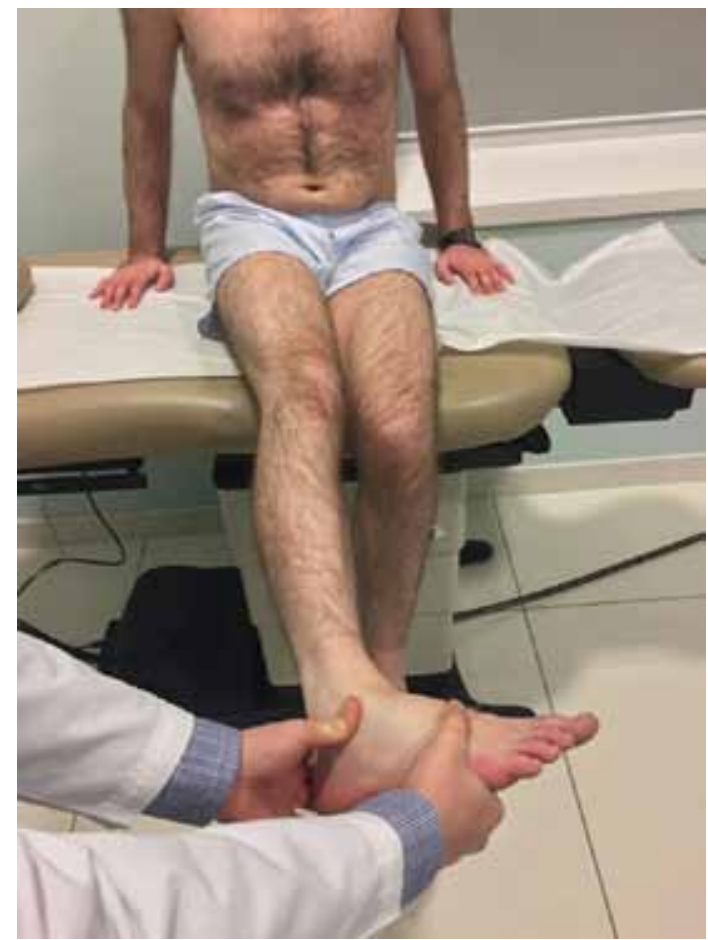

Şekil 6. Oturur pozisyonda priformis germe testi.

hasta supin ve prone pozisyonda yatarken değerlendirilen kalça rotasyon dereceleri ile kıyaslanmalıdır.

Priformis germe testi, hasta oturur pozisyonda iken diz eklemi ekstansiyona getirilerek değerlendirilebilen bir testtir (Şekil 6). Ayak topuktan kavranır; kalça eklemi adduksiyon ve iç rotasyona zorlanır ve hastadan dirence karşı abduksiyon ve dış rotasyon yapması istenir. Ağrının varlığı, priformis sendromunu ya da dış rotatorlardaki bir tendiniti akla getirir.

Modifiye FABER testinde, hasta oturur pozisyonda iken kalça eklemi fleksiyon, abduksiyon ve dış rotasyon pozisyonuna alınır (Şekil 7). Bu testle, ağrılı 




Şekil 7. A, B. Oturur pozisyonda modifiye FABER testinin uygulanışı (A). Diz laterali ile muayene masası arasındaki mesafe (beyaz ok) (B).

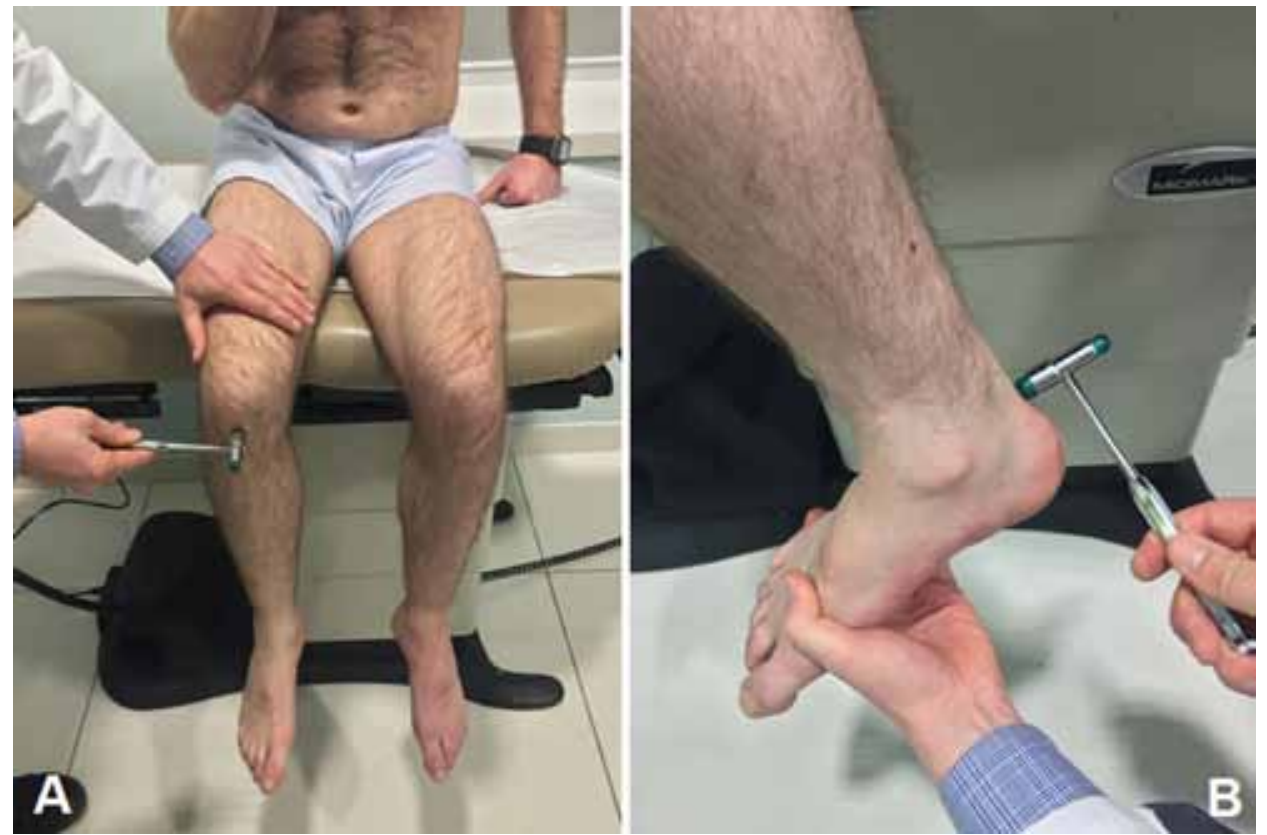

Şekil 8. A, B. Patellar tendon refleksi (L4 sinir kökü) (A) ve Aşil tendon refleksi (S1 sinir kökü) (B).

eklem içi patolojileri dışında iliotibial bant kontraktürü de değerlendirilebilmektedir. Diz laterali ile muayene masası arasındaki mesafe, kontraktür derecesini gösterir.

Oturur pozisyonda, alt ekstremiteler mutlaka vasküler/lenfatik sistem açısından da değerlendirilmelidir; periferik arter nabızları (popliteal arter, tibialis anterior ve posterior, dorsalis pedis), ekstremitede şişlik ve ödem mevcudiyeti, cilt dokusunun durumu kaydedilmelidir. Ayrıca, otururken alt ekstremitelerin nörolojik durumu hakkında fikir verebilecek refleks muayeneler de yapılmalıdır (Şekil 8). 


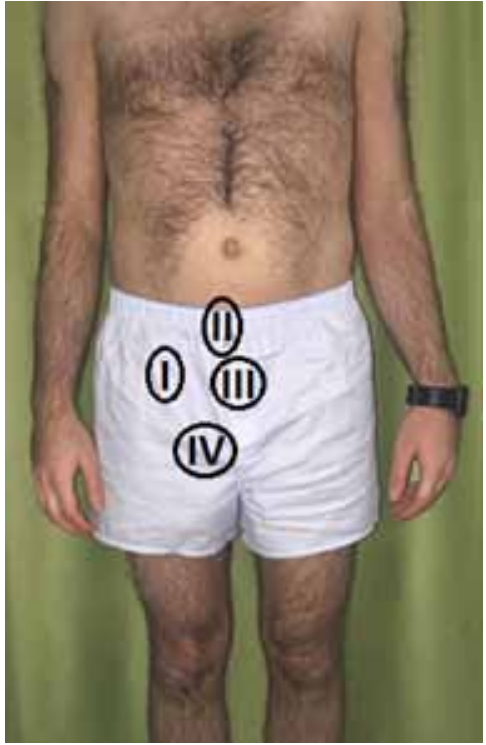

Şekil 9. Kalça anteriorunda palpe edilebilecek noktalar.
Tablo 2. Kalça anteriorunda ayırııı tanılar

\begin{tabular}{|c|c|c|c|}
\hline $\begin{array}{l}\text { Bölge I } \\
\text { (kalça eklemi) }\end{array}$ & $\begin{array}{l}\text { Bölge II } \\
\text { (suprapubik bölge) }\end{array}$ & $\begin{array}{l}\text { Bölge III } \\
\text { (pubik bölge) }\end{array}$ & $\begin{array}{l}\text { Bölge IV } \\
\text { (adduktor bölge) }\end{array}$ \\
\hline $\begin{array}{l}\text { - Labral yırtıklar, } \\
\text { osteokondral } \\
\text { serbest cisimler, } \\
\text { eklem kıkırdak } \\
\text { hasarı } \\
\text { - Kütleyen kalça } \\
\text { sendromu } \\
\text { (snapping hip) } \\
\text { - Rektus femoris } \\
\text { avulsiyonu } \\
\text { - Femur boynunda ya } \\
\text { da pubik ve iskial } \\
\text { kolda stres kırıkları }\end{array}$ & $\begin{array}{l}\text { - Atletik pubalji } \\
\text { - Abdominal herniler } \\
\text { - Sinir sıkışmaları } \\
\text { (ilioinguinal, } \\
\text { iliohipogastrik, } \\
\text { genitofemoral } \\
\text { sinirler) }\end{array}$ & $\begin{array}{l}\text { - Osteitis pubis } \\
\text { - Pubik simfizis } \\
\text { instabilitesi } \\
\text { - Pubis osteomiyeliti } \\
\text { - Pubik kol stres } \\
\text { kırıkları } \\
\text { - Sinir sıkışmaları } \\
\text { (ilioinguinal, } \\
\text { iliohipogastrik, } \\
\text { genitofemoral } \\
\text { sinirler) }\end{array}$ & $\begin{array}{l}\text { - Adduktor/Gracilis } \\
\text { yırtıkları } \\
\text { - iliopsas tendon } \\
\text { yırtıkları ve } \\
\text { avulsiyonları } \\
\text { - Sinir sıkışmaları } \\
\text { (obturator ve } \\
\text { pudental sinirler) }\end{array}$ \\
\hline - Meraljia parestetika & & & \\
\hline
\end{tabular}

\section{YATARKEN FIZIK MUAYENE (SUPIN POZISYON)}

Kalça eklemine yönelik önemli birçok muayene yatarken yapılır. Çok sayıda spesifik muayene testi de supin pozisyon için tanımlanmıştır.

Sırtüstü yatarken kalça muayenesine, öncelikle her iki ekstremite uzunluklarının değerlendirilmesi ile başlanmalıdır. Bu amaçla, hem umblikustan her iki mediyal malleole olan mesafelerin değerlendirildiği fonksiyonel bacak uzunlukları, hem de SiAS - mediyal malleol arası mesafelerin değerlendirildiği gerçek bacak uzunlukları ölçülmelidir.

Ardından, palpasyonla pelvis ve kalça eklem muayenesine devam edilir. Öncelikle supin pozisyonda yatan bir hastada ağrılı noktanın neresi olduğunun sorulması ve o bölgenin palpe edilmesi, atletik pubalji, osteitis pubis ya da adduktor tendinit gibi kalça eklemi dışı patolojileriyle eklem içi patolojilerin ayırt edilmesini kolaylaştıracaktır (Şekil 9, Tablo 2).

"Log-roll” testi olarak da adlandırılan pasif rotasyon testi, kalça ekleminin supin pozisyonda rotasyonlarının değerlendirildiği bir testtir. Kalça ve diz eklemi tam ekstansiyonda iken, pasif olarak kalça iç ve dış rotasyonuna bakılır (Şekil 10). Pasif rotasyon hareketleri ile ağrı mevcudiyeti, kalça eklem irritabilitesine işaret eder. Eklem içi patolojiler için oldukça indikatif ve sensitif bir testtir; ancak, spesifik değildir; yanlış negatif sonuç olasılığı yüksektir. Bu test sırasında pasif olarak dış rotasyonda artış olması, kemik versiyon anormallikleri olmaksızın kapsüler laksiteye de işaret edebilir.
Supin pozisyonda kalça ekleminde, özellikle fleksiyon, iç ve diş rotasyon ile abduksiyon ve adduksiyon hareket genişliklerine ve ilgili hareketlerde kas gücüne bakılmalıdır. Fleksiyon genişliğine, kalça eklemi nötral abduksiyon ve adduksiyonda iken diz eklemi fleksiyona getirilerek bakılır. Fleksiyon dereceleri $120^{\circ}$ üstünde ise normal kabul edilmelidir. Kalça iç ve dış rotasyonuna, log-roll testinde olduğu gibi, kalçalar ve diz eklemleri tam ekstansiyonda iken bakılabilir. Ancak, rotasyonel muayene mutlaka kalça ve diz eklemi $90^{\circ}$ fleksiyonda iken tekrar edilmelidir. Normalde, iç rotasyon $25^{\circ}-30^{\circ}$, dış rotasyon ise $40^{\circ}$ civarındadır. Ayrıca, kalça fleksiyonu ile rotasyonların birlikte değerlendirilmesi de özellikle kalça eklemine ilişkin eklem içi patolojilerde ve kalça eklemi sıkışma (FAS) sendromunda tanıya yardımcı olabilir. Kalça eklemi fleksiyonda iken iç rotasyona getirildiğinde oluşan kasık ağrısı anterior FAS ile, fleksiyon ve dış rotasyon pozisyonu ile kasık ve/veya posterior kalça ağrısı oluşması ise posterior FAS ile ilişkilendirilebilir. Supin pozisyonda kalça eklemine ilişkin abduksiyon ve adduksiyon hareket geniş̧likleri değerlendirilirken, mutlaka karşı kalçanın Si̇AS'ı diğer el ile sabitlenmeli ve bu hareketlerle pelvisin dönmesi engellenmelidir. Hareketin son noktasında SIAS ve pelvis dönmeye başlar. Bu noktadaki dereceler kaydedilir. Normal abduksiyon $30^{\circ}-45^{\circ}$, adduksiyon ise $20^{\circ}$ civarındadır. Abduktor ve adduktor adale güçlerine ise diz ve kalça eklemleri tam ekstansiyonda ve fleksiyonda iken ayrı ayrı bakılmalıdır. Abduksiyon gücünün kalça ve diz eklemi fleksiyonda iken değerlendirilmesi kalça abduktorlarını izole değerlendirme şansı verir (Şekil 11). 



Şekil 10. A, B. “Log roll” testinde kalça iç rotasyonu (A) ve kalça dış rotasyonu (B).
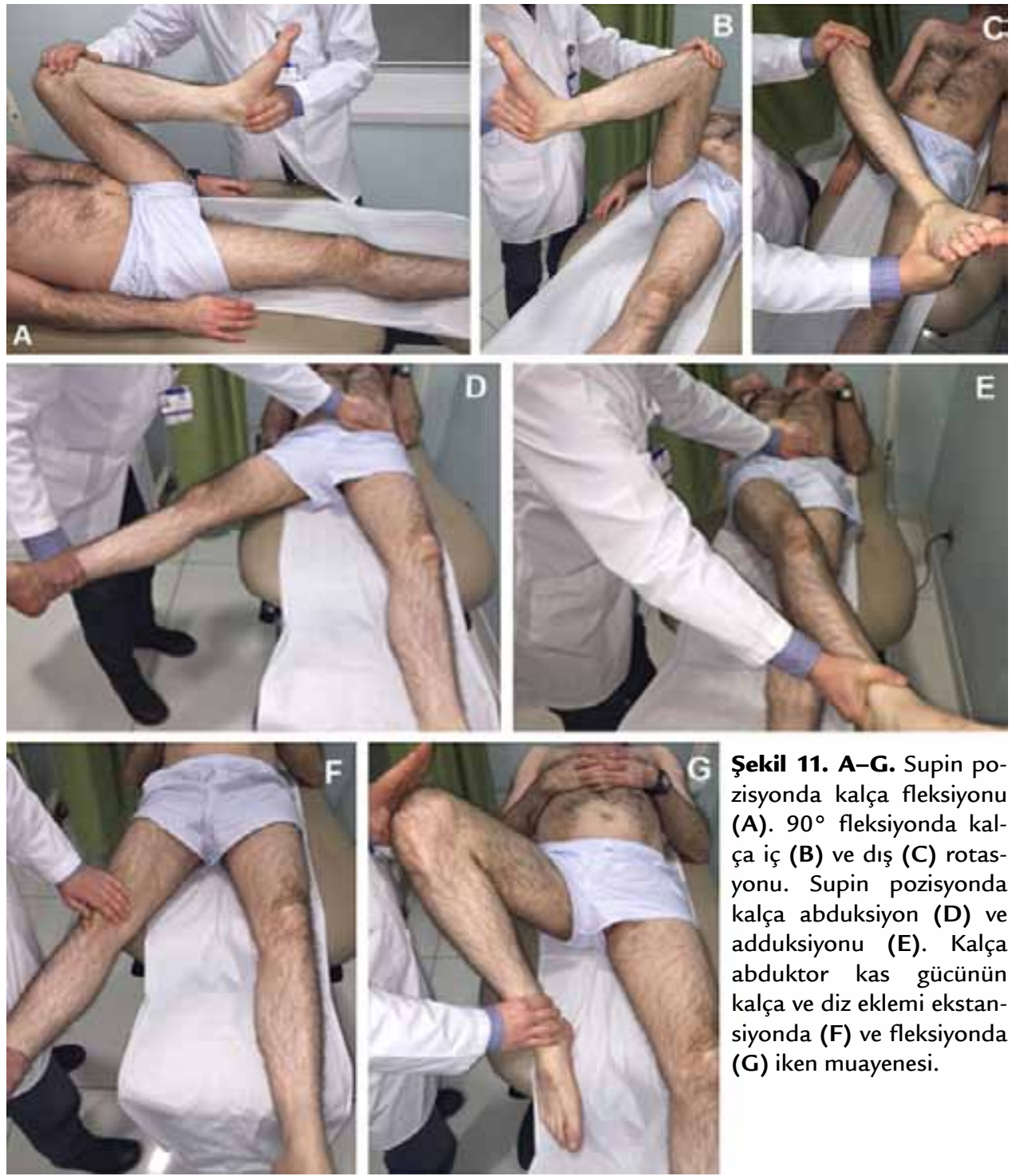

Şekil 11. A-G. Supin pozisyonda kalça fleksiyonu (A). $90^{\circ}$ fleksiyonda kalça iç $(B)$ ve diş $(C)$ rotasyonu. Supin pozisyonda kalça abduksiyon (D) ve adduksiyonu (E). Kalça abduktor kas gücünün kalça ve diz eklemi ekstansiyonda (F) ve fleksiyonda (G) iken muayenesi. 


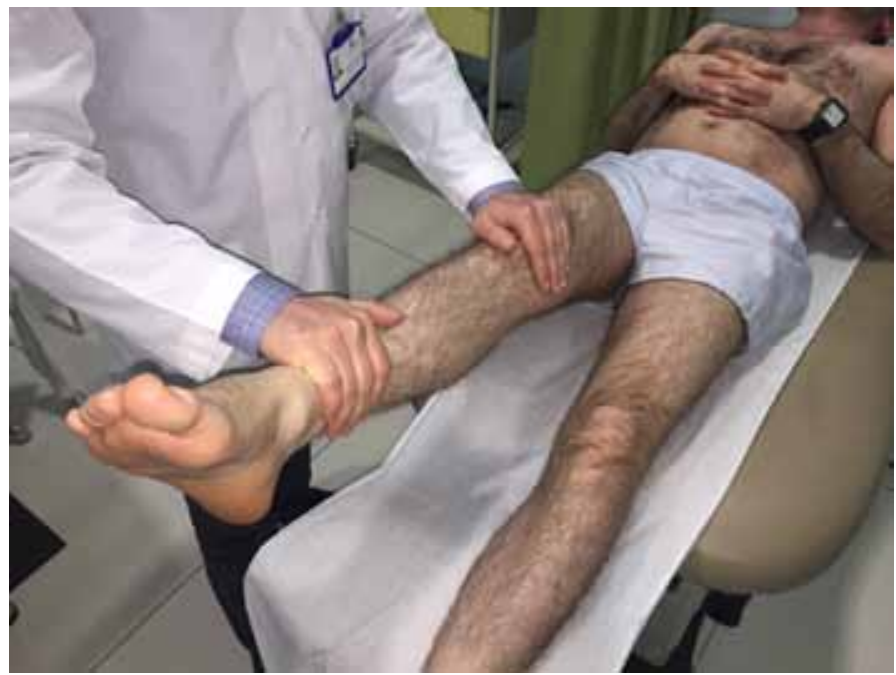

Şekil 12. Dirence karşı düz bacak kaldırma testi (Stitchfield testi).
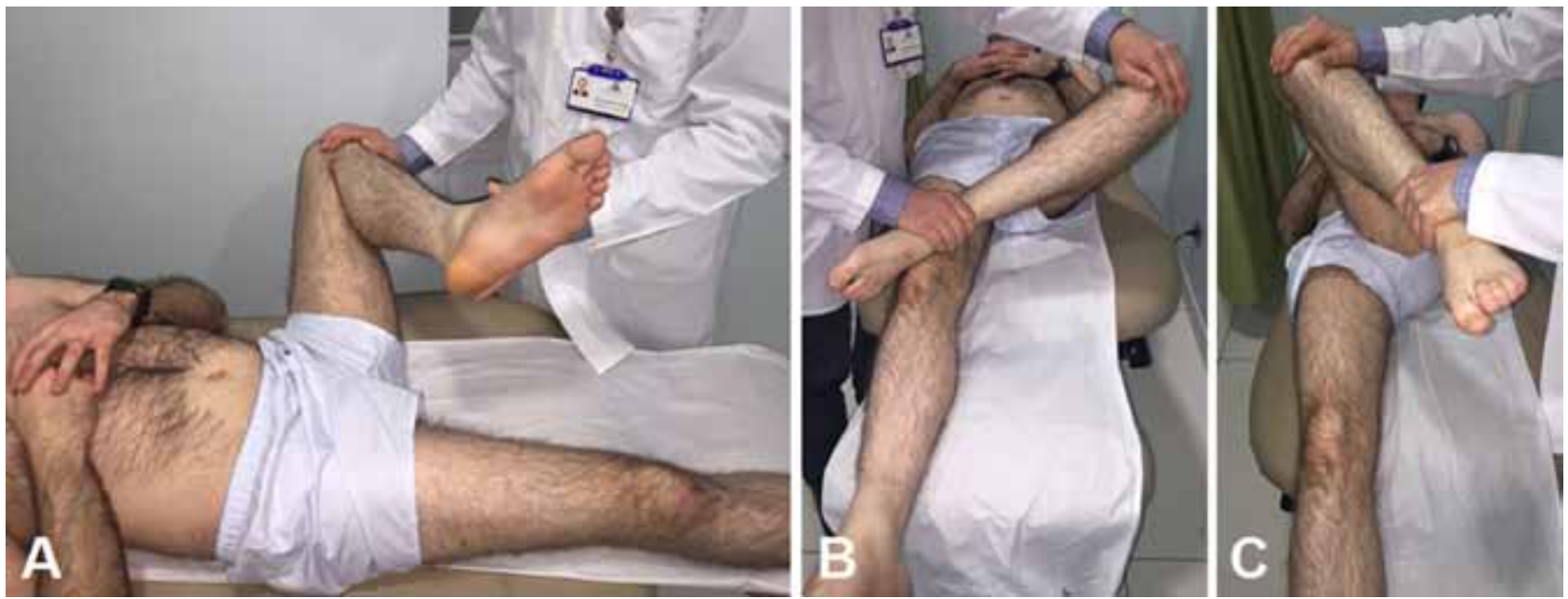

Şekil 13. A-C. FABER (Patrick) testi (A ve B) ve FADIR testi (C).

Supin pozisyonda, yukarıda tanımlanan eklem hareket geniş̧liği muayenelerinin ardından eklem hareketlerinde genel olarak tüm yönlerde saptanan azalma, ileri kalça osteoartritini ve adheziv kapsüliti akla getirecektir. Eklem hareket genişliğinde artma ve hipermobilite ise, yapısal instabilite, kalça eklem displazisi ve bağ dokusu hastalıkları ile ilişkili olabilir. Genel olarak iç rotasyonda artış, dış rotasyonda azalma femoral anteversiyon artışını gösterir. İç rotasyonda azalma ve dış rotasyonda artma ise femoral retroversiyon ile ilişkilendirilebilir.

Kalça eklemine yönelik uygulanan spesifik ortopedik muayene yöntemlerinin büyük bir kısmı supin pozisyonda uygulanmaktadır.

Dirence karşı düzbacak kaldırma testinde (Stitchfield testi), hasta supin pozisyonda yatarken kalçasını aktif olarak $30^{\circ}-40^{\circ}$ fleksiyona getirir. Hekim, diz üstünden fleksiyona karşı direnç uygular (Şekil 12). Bu manevra ile antero-superior labrum, iliopsoas, rektus femoris ve alt abdominal adalelere yük biner ve ilişkili bölge patolojilerinde ağı ortaya çıkar.

FABER (Patrick) testinde, muayene edilecek olan kalçaya sırasıyla fleksiyon, abduksiyon ve dış rotasyon manevraları uygulanır (Şekil 13 A ve B). Oldukça sık uygulanan bu testte, kalçanın anterioru ve derin lateralinde ağrı olması, eklem içi bir patolojiyi ve/veya iliopsoas tendon patolojilerini akla getirmelidir. FABER testi ile hasta sadece posterior lokalizasyonlu kalça ağrısı da tanımlayabilir. Özellikle karşı kalça posteriorunda ağrı mevcudiyeti, sakroiliak eklem patolojilerini ön plana çıkarmaktadır. Ayrıca, bu testte diz eklemi laterali ile muayene masası arasındaki mesafe farkı da iliotibial 


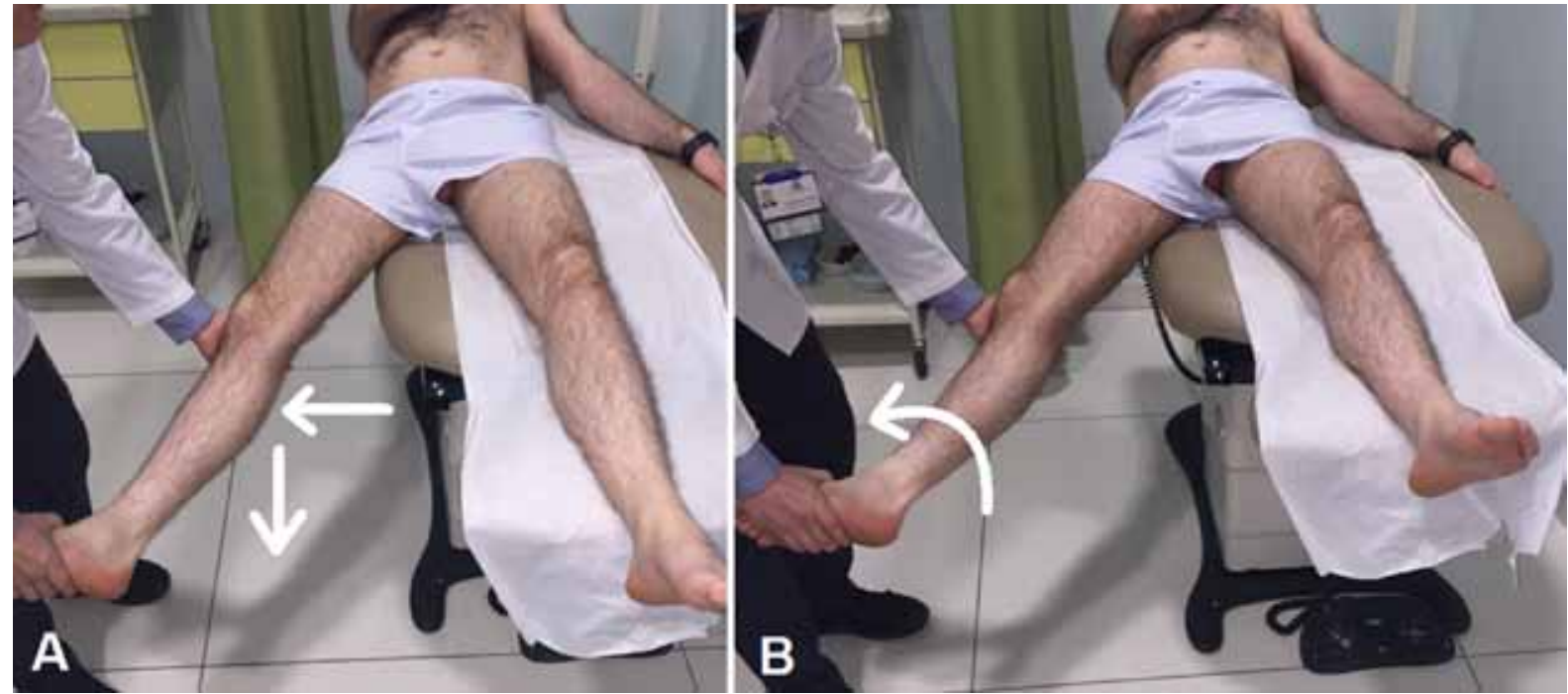

Şekil 14. A, B. Posterior sıkışma testinin uygulanışı. Kalça ekleminde ekstansiyon ve abduksiyon (A), dış rotasyon (B) manevraları.

bant kontraktürü açısından anlamlı olabilir ya da kalça sıkışma sendromunun şiddetine ve iliopsoas gerginliğine işaret edebilir. Spesifik kalça muayeneleri içerisinde en sık uygulanan testlerden birisi olan FABER testinde, ağrı mevcudiyeti anterior ve anterolateral lokalizasyonlu ise, labral yırtık, eklem içi osteokondral patoloji, posterior FAS, iliopsoas tendon patolojileri ve iliotibial bant gerginliği ile ilişkili iken, posterior lokalizasyonlu ağrılarda sakroiliak eklem patolojileri akılda tutulmalıdır.

FABER ardından sıklıkla uygulanan bir diğer test de, FADIR ya da diğer adıyla anterior sıkışma (impingement) testidir; bu, anterior ve anterolateral kalça patolojilerini (FAS ve labral yırtık) ortaya koymada oldukça spesifik bir testtir. Kalça eklemine sırasıyla, fleksiyon, adduksiyon ve iç rotasyon manevraları uygulanır (Şekil $13 \mathrm{C}$ ). Hastanın kasık önünde ağıı tanımlaması, testin pozitif olduğunu gösterir.

Posterior sıkışma testi, posterior rim impingement testi olarak da adlandırılır. Adından anlaşılacağı üzere, özellikle kalça eklemindeki posterior ve posterolateral yerleşimli patolojileri ortaya çıkarmaya yönelik uygulanan bir testtir. Muayene sırasında hasta muayene masasının kenarına iyice yaklaştırılır ya da muayene masasının ayak kısmına doğru kalçasını kaydırır. Bu sayede, kalça eklemine rahatlıkla ekstansiyon yaptırılabilir. Kalça ekstansiyonu ile birlikte abduksiyon ve dış rotasyon manevraları uygulanır ve posteriorposterolateral lokalizasyonlu ağrı mevcudiyeti araştırilır (Şekil 14). Posterior asetabular labrum patolojileri ve posterior sıkışma sendromunda test pozitifliği anlamlıdır. Ancak posterior lokalizasyonlu sıkışma patolojileri anterior ve anterolateral patolojilere kıyasla oldukça seyrektir.

Kalça ekleminde femoroasetabular uyumluluğu değerlendiren testler, dinamik kalça rotasyon testleri olarak da bilinen, dinamik internal rotasyon sıkışma (DIRIT) ve dinamik eksternal rotasyon sıkışma (DEXTRIT) testleridir. DIRIT testinde, karşı kalça ve diz eklemleri hasta tarafindan fleksiyon pozisyonunda tutulur. Bu sayede lomber lordoz azaltılmış ve pelvis sabitlenmiş olur. Muayene edilecek olan kalça eklemi fleksiyona getirildikten sonra sırasıyla, maksimum iç rotasyon, adduksiyon ve ekstansiyon manevraları uygulanır (Şekil 15). Hastanın bu manevralar ile tipik olarak kasık ağrısı tanımlaması, eklem içi bir kalça patolojisini akla getirir. DIRIT testinde, anterior femoroasetabular uyumluluk değerlendirilmektedir; bu test, anterior FAS patolojilerinde oldukça duyarlıdır. DEXTRIT testine de, DIRIT testindeki gibi karşı kalça ve diz eklemleri fleksiyona getirilerek başlanır. Muayene edilecek olan kalça eklemi fleksiyona getirildikten sonra sırasıyla, maksimum dış rotasyon, abduksiyon ve ekstansiyon manevraları uygulanır (Şekil 16). Hastanın kasık ağrısı tanımlaması, eklem içi bir kalça patolojisini akla getirir. Bu test, özellikle superolateral ve posterior FAS değerlendirmesi için anlamlıdır. Ayrıca, anteroinferior kalça instabilitesi, anteroinferior asetabular hipoplazi, ligamentum teres yırtığı ve kapsüler laksitede de bu test ile ağrı oluşabilir.

Ovalama (Scour) testi olarak tanımlanan test, DEXTRIT ve DIRIT testlerinin kombine şekilde uygulandığı bir manevradır. Karşı kalça fleksiyonda iken, muayene edilecek kalça fleksiyona alındıktan sonra 

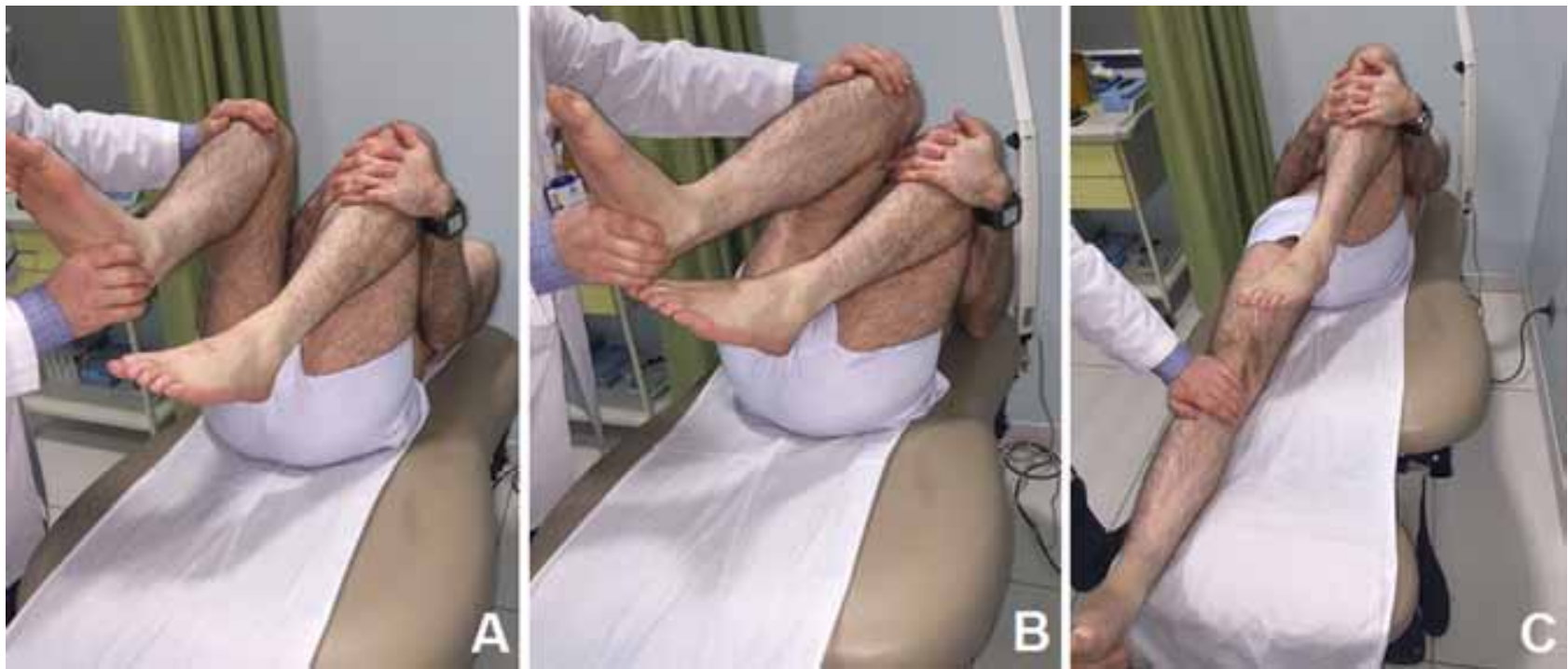

Şekil 15. A-C. Dinamik internal rotasyon sıkışma testi (DIRIT). Fleksiyon (A), iç rotasyon ve adduksiyon (B), ekstansiyon (C).


Şekil 16. A-C. Dinamik eksternal rotasyon sıkışma testi (DEXTRIT). Fleksiyon (A), dış rotasyon ve abduksiyon (B), ekstansiyon (C).

kalçaya aksiyel yüklenme uygulanır ve kalça sırasıyla iç rotasyon-adduksiyon-ekstansiyon-dış rotasyonabduksiyon-fleksiyon manevralarına maruz bırakılır (Şekil 17). Bu şekilde, kalça eklemi saat yönünde (sağ kalça için) ya da saat yönünün tersinde (sol kalça için) çevrilmiş olur. Hastanın bu manevra ile kasık ağrısı hissetmesi ve klik hissi tanımlaması, eklem içi bir patolojiye işaret eder. Anterior sıkışma testi ile ağrı tanımlamayan ve anterior FAS şüphesi olan hastalarda bu test kullanılmalıdır.

"Butterfly Goalie" testi ise, diğer testlerden farklı olarak, superior-posterior asetabular rim ve FAS patolojilerini ortaya koyan bir testtir. Supin pozisyonda kalçaya sırasıyla, fleksiyon, abduksiyon ve iç rotasyon manevraları yaptırılır ve ağrı mevcudiyeti araştırılır (Şekil 18).

Anterior korkutma (apprehension) ve yerleştirme (relocation) testleri, displazik kalçalarda bakılabilecek testlerdir. Korkutma testi, posterior kalça sıkışma testi gibi uygulanır (Şekil 19 A). Bu test sırasında hasta, kalçasının anteriora doğru kaydığını ifade eder. Bu, yapısal anterior instabilite varlığına işaret eder. Yerine oturtma ya da yerleştirme testinde ise hastanın kalçasına "Butterfly" manevrası uygulanır (Şekil 19 B). Yani, ekstansiyon, abduksiyon ve dış rotasyondaki kalçanın fleksiyon ve iç rotasyona alınması sonucunda hasta, 

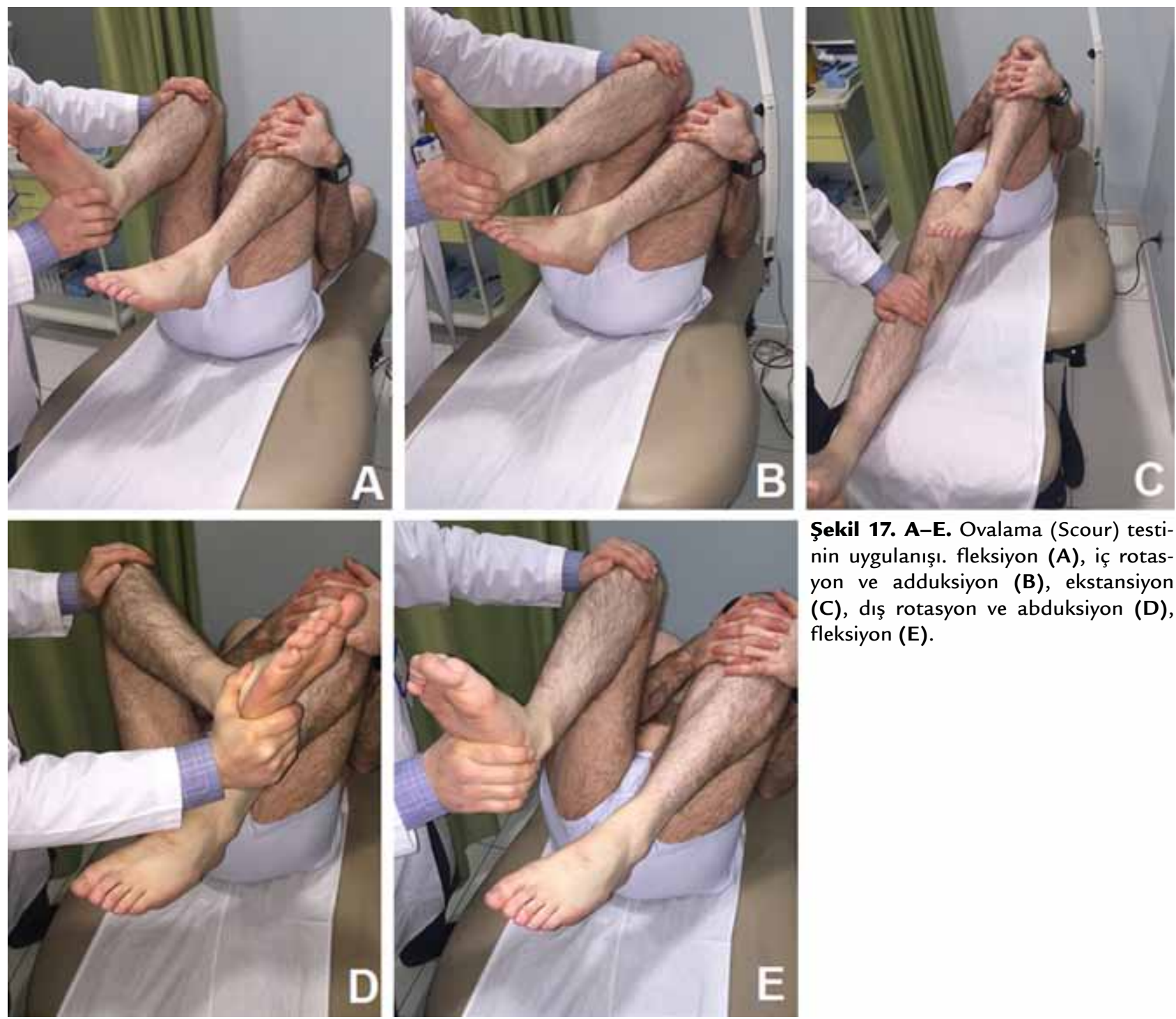

Şekil 17. A-E. Ovalama (Scour) testinin uygulanışı. fleksiyon (A), iç rotasyon ve adduksiyon (B), ekstansiyon (C), dış rotasyon ve abduksiyon (D), fleksiyon (E).
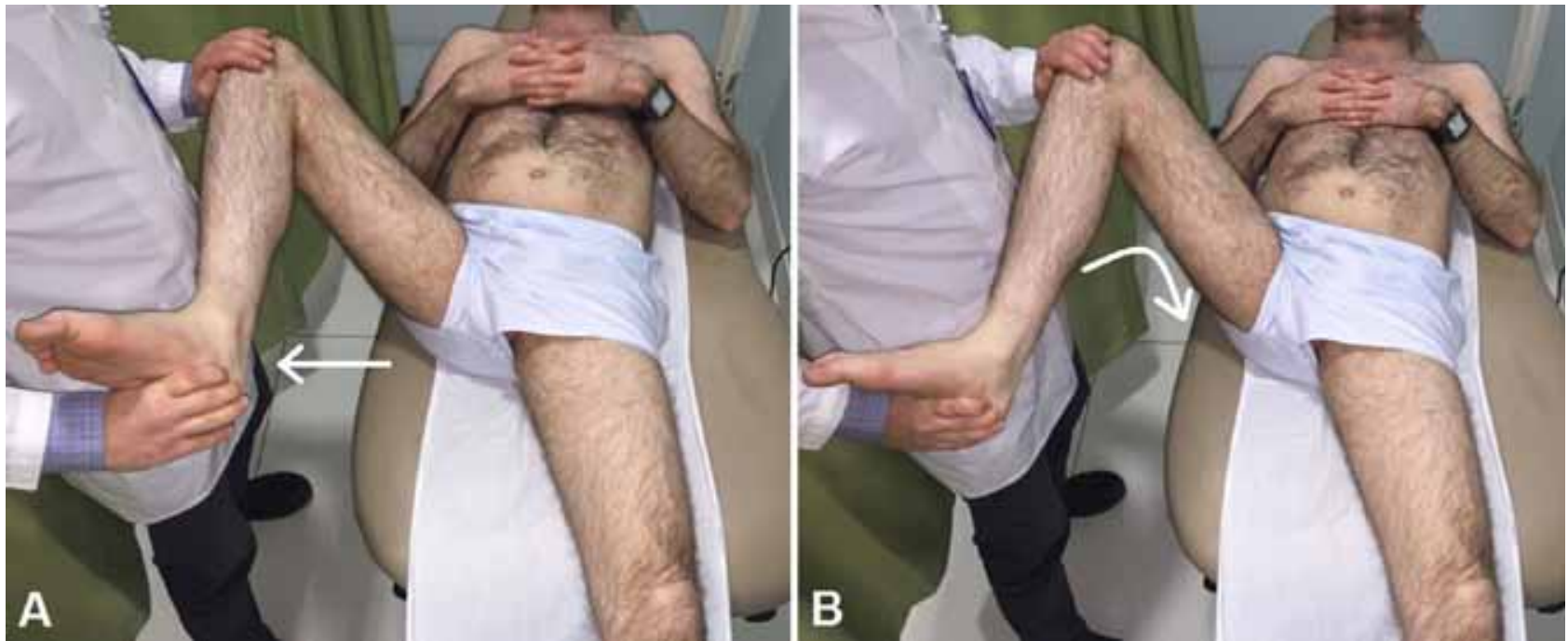

Şekil 18. A, B. "Butterfly Goalie” testinin uygulanışı. Fleksiyon pozisyonunda abduksiyon (A) ve iç rotasyon (B). 

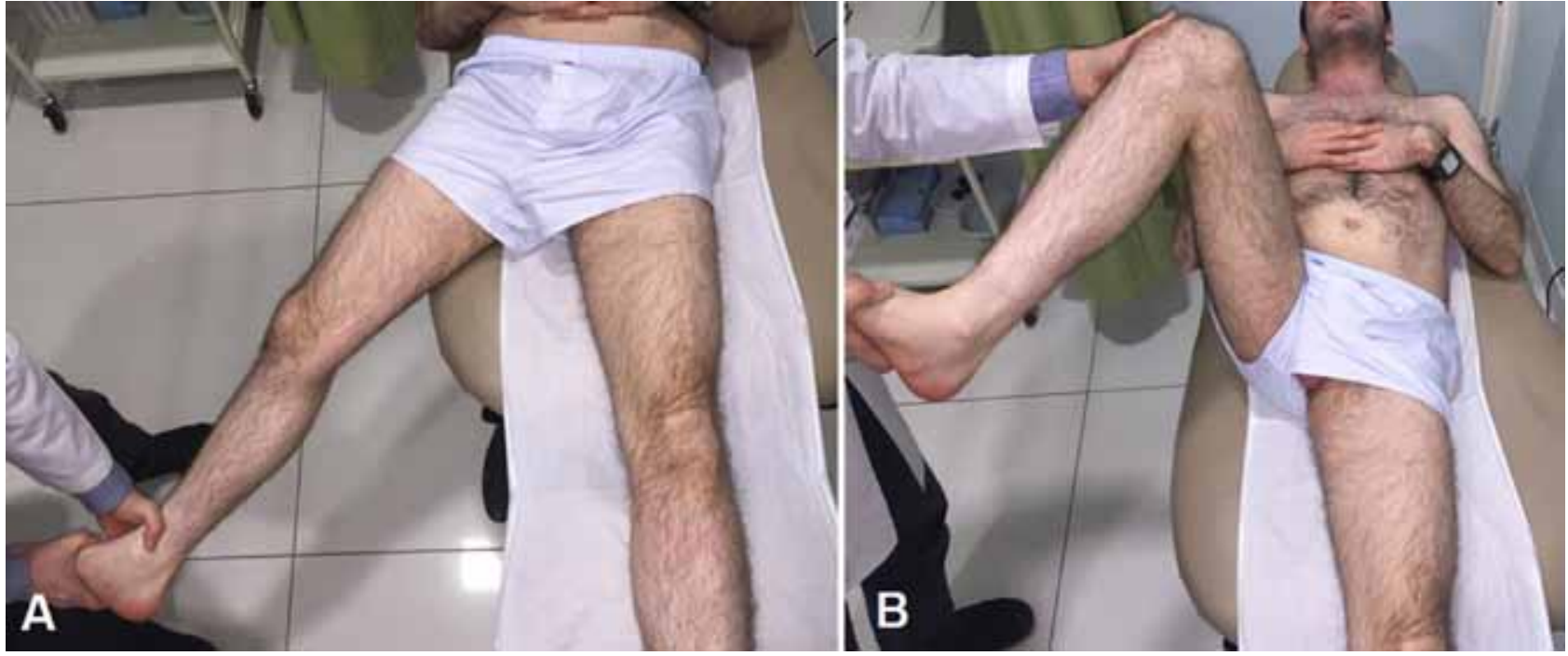

Şekil 19. A, B. Anterior korkutma (apprehension) testi (A) ve yerleştirme (relocation) testi (B).
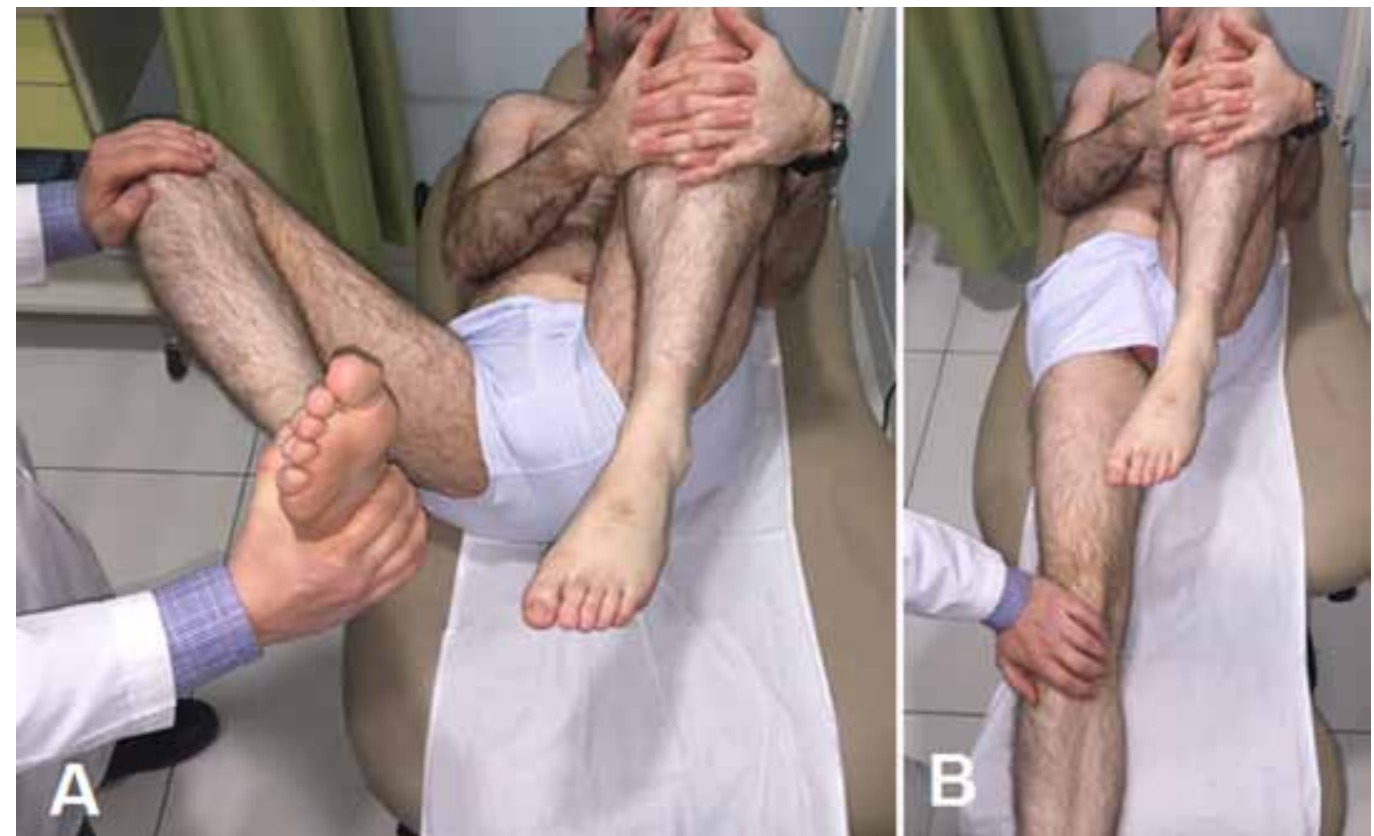

Şekil 20. A, B. İnternal (psoas) snapping testi. fleksiyon-abduksiyon-dış rotasyon (A) ve ekstansiyonadduksiyon-iç rotasyon (B).

kalçasında stabilite tanımlar ve hissettiği huzursuzluğun ortadan kalktığını ifade eder. Her iki test de femur başı lateralizasyonunu gösterir.

Supin pozisyonda mutlaka, eklem içi patolojiler dışında, periartiküler yapılardaki problemler sonucu oluşabilecek kalça ağrısı nedenleri de değerlendirilmelidir. Kütleyen kalça (snapping hip) sıklıkla, kalça ağrısı ile birliktelik gösterebilecek bir patolojidir. Kalçada kütleme hissi, kondral bir lezyonun varlığına işaret edebileceği gibi, eksternal nedenlerden de kaynaklanabilir. İnternal (psoas) ve eksternal (iliotibial bant) kaynaklı olabilen bu patolojilerin ayrımı fizik muayene ile yapılabilir. Internal (psoas) snapping testinde, supin pozisyonda yatan ve karşı kalçasını fleksiyonda tutan hastada muayene edilen kalça, fleksiyon-abduksiyon-dış rotasyondan ekstansiyon-adduksiyon-iç rotasyona getirilir (Şekil 20). Bu esnada kalçada bir atlama hissi oluşursa, iliopsoas tendiniti akla getirilmelidir.

Thomas testi, supin pozisyonda kalça eklemine ait kas spastisitesi ya da kontraktürlerin değerlendirildiği 

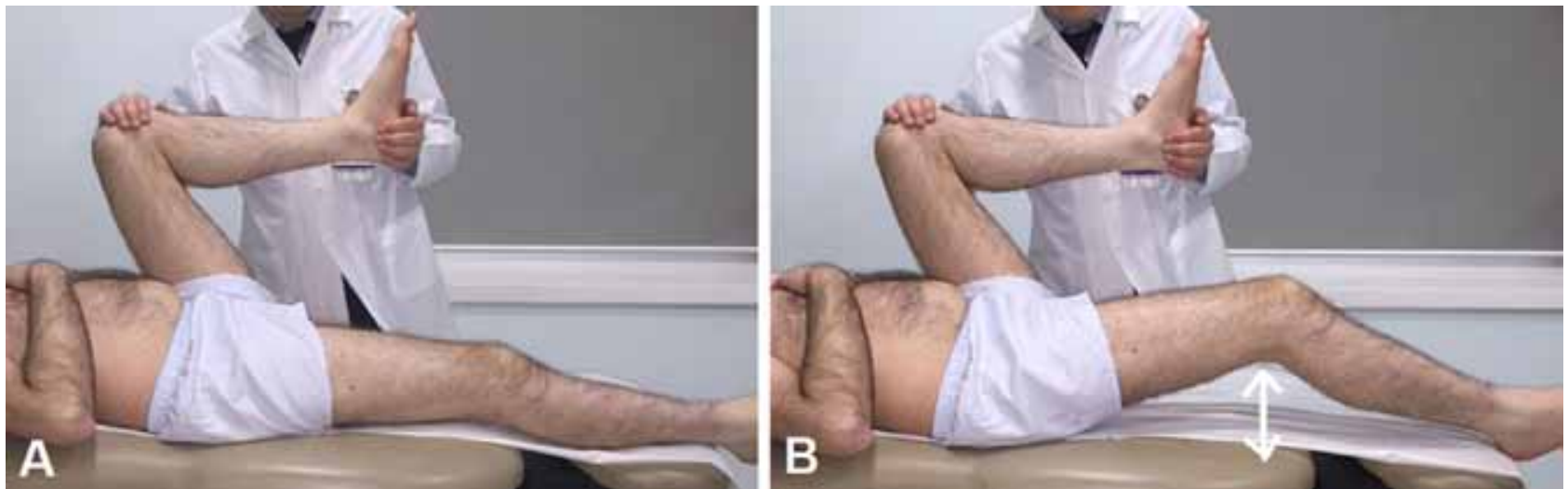

Şekil 21. A, B. Thomas testinin uygulanışı. Test negatif (A) ve test pozitif (kontraktür derecesi: beyaz ok) (B).
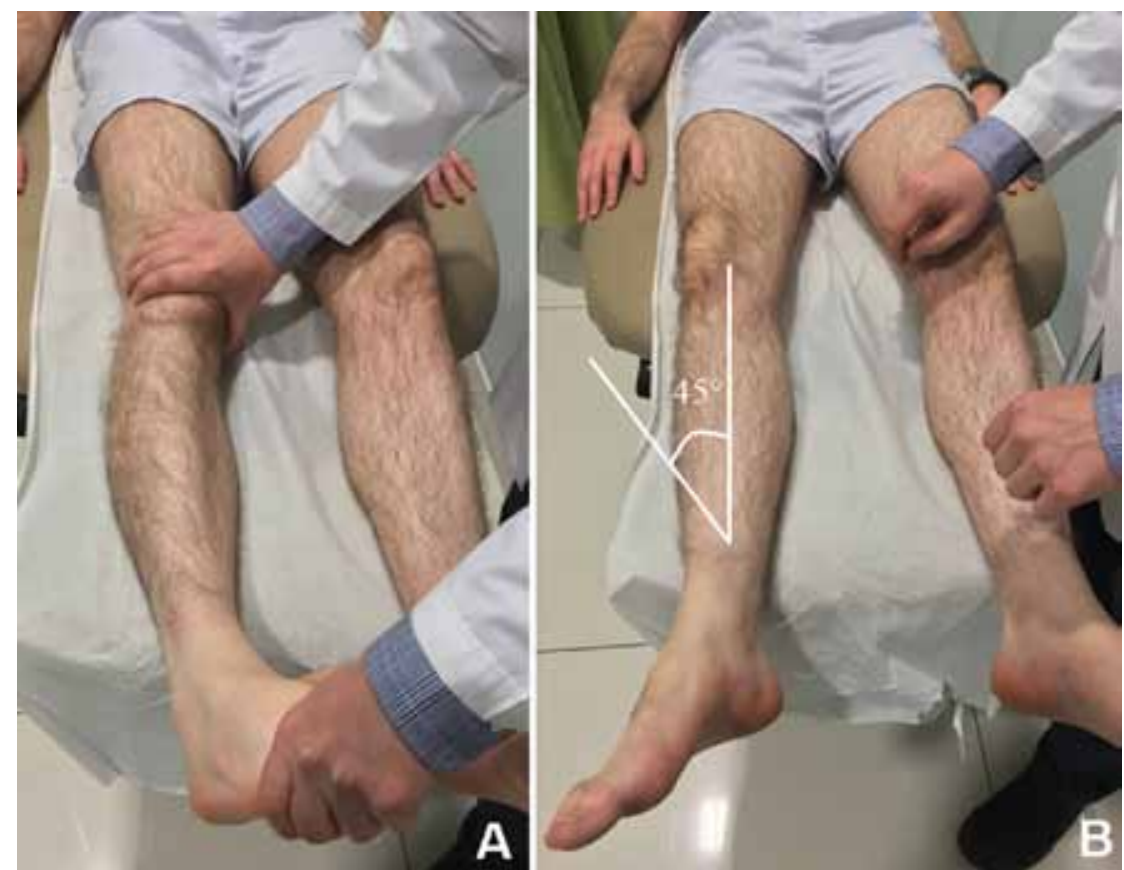

Şekil 22. A, B. Dial testinin uygulanışı. Alt ekstremitenin pasif iç rotasyonu (A). Ekstremitenin kendi halinde dış rotasyona dönmesinin gözlenmesi (B).

testlerden biridir. Supin pozisyonda yatan hastada karşı kalça fleksiyona getirilir ve lomber lordoz düzleştirilir. Eğer diğer kalça pasif olarak fleksiyona geliyorsa, iliopsoas spastisitesi ya da kontraktürüne işaret eder (Şekil 21). Bu testte, hiperlaksitesi ya da lomber hiperlordozu olan hastalarda yanlış negatif sonuçlar alınabilir.

Dial testi, kapsüler laksiteyi değerlendiren bir testtir. Supin pozisyonda yatan, kalça ve diz eklemleri ekstansiyonda olan hastada, kalça pasif olarak iç rotasyona getirilir ve ardından bırakılarak ekstremitenin kendi halinde dış rotasyona dönmesi gözlenir (Şekil 22). Kalça ekleminde vertikal hattan $45^{\circ}$ 'den daha fazla dış rotasyon gözlenmesi, kapsüler laksiteye işaret eder.
Son olarak, diğer muayenelere geçmeden önce supin pozisyonda yatan hastada lomber patolojileri değerlendiren düz bacak kaldırma ve Laseque testleri gibi, $L 4, \mathrm{~L} 5$ ve S1 sinir köklerinin değerlendirildiği germe testlerine de bakılmalıdır.

\section{YATARKEN FiZIK MUAYENE (LATERAL DEKÜBIT POZISYON)}

Yan yatar (lateral dekübit) pozisyonda kalça eklem muayenesine, abduksiyon ve ekstansiyon hareket genişliklerinin değerlendirilmesi ile başlanmalıdır. Özellikle ekstansiyon genişliği en iyi bu pozisyonda değerlendirilir. Dirence karşı aktif kalça abduksiyonu ile 

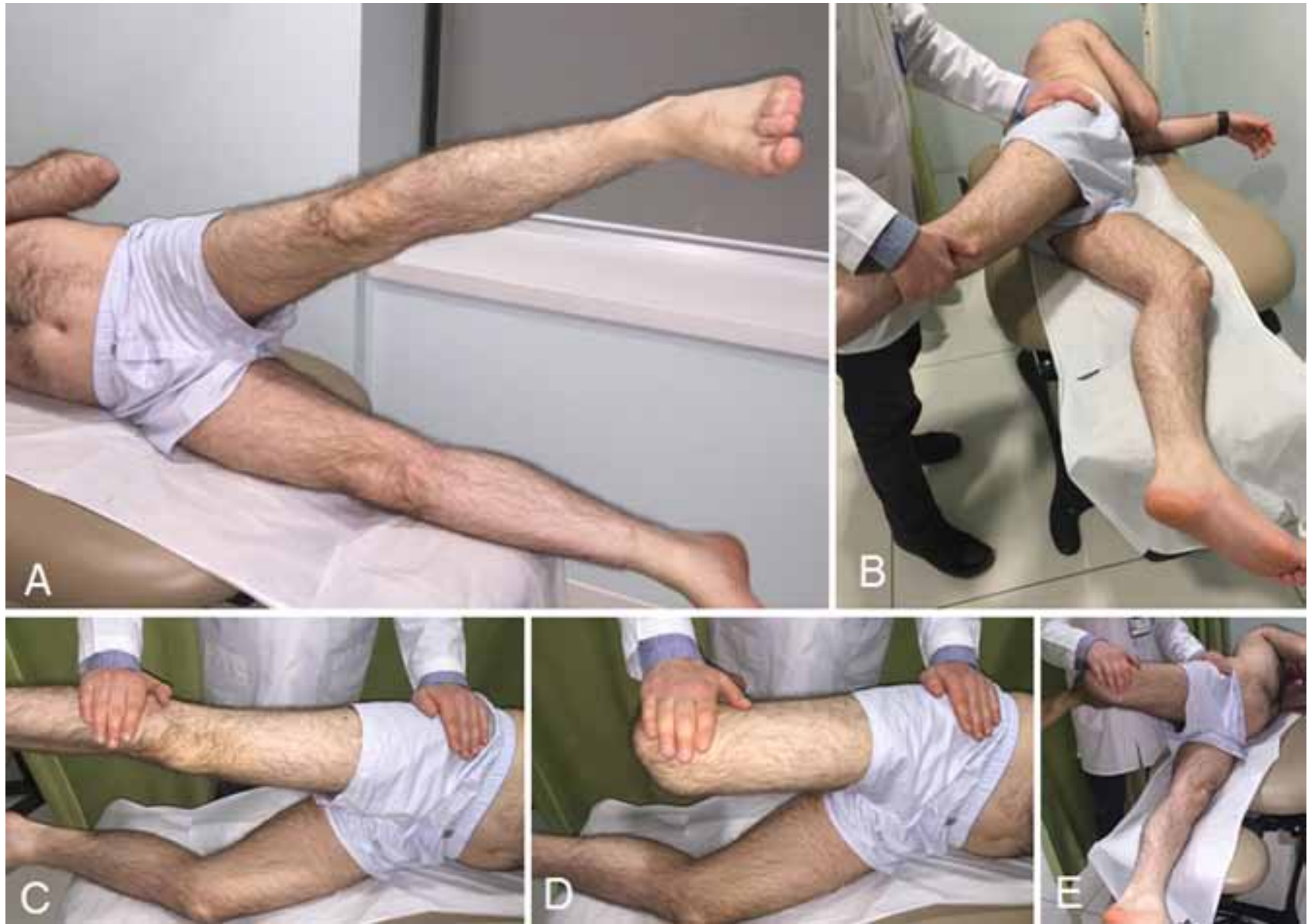

Şekil 23. A-E. Lateral dekübit pozisyonda abduksiyon (A), ekstansiyon hareket genişliklerinin gözlenmesi (B). Abduktor kas gücünün kalça nötral pozisyonda ve diz ekstansiyonda (C), kalça nötral pozisyonda ve diz fleksiyonda (D), kalça ekstansiyonda ve diz fleksiyonda (E) değerlendirilmesi.

kalça abduktorları değerlendirilebilir. Bu teste diz eklemi fleksiyona alınıp bakılırsa, sadece gluteus medius hakkında değerlendirme yapılmış olur, çünkü gluteus maksimus iliotibial bant ile birlikte gevşemiştir. Diz ekstansiyona getirildiğinde, tüm abduktor adale gücü değerlendirilebilir. Eğer kalça eklemi ekstansiyona getirilerek abduksiyon gücüne bakılırsa, gluteus maksimus gücü hakkında değerlendirme yapılmış olur (Şekil 23).

Palpasyonla, trokanter majör ve etrafindaki hassasiyet varlığı araştırılmalıdır. Trokanter majörün anteriorundaki ağrılarda gluteus minimus, superiorundaki ağrılarda gluteus medius, posteriorundaki ağrılarda ise trokanterik bursit ya da trokanterik ağrı sendromu akla getirilmelidir (Şekil 24). Trokanter majörün 4-5 cm'den daha fazla posteriorunda palpasyon ile ağrı ortaya çıkması ise, priformis sendromu ile ilişkilendirilebilir.

Fizik muayene ile lateral dekübit pozisyonda da femoroasetabular uyumluluk değerlendirilebilir. Lateral dekübit pozisyonda uygulanan FADIR testi, supin pozisyonda fleksiyon, adduksiyon ve iç rotasyon manevralarının yan yatar pozisyonda iken uygulanması ile gerçekleştirilir (Şekil $25 \mathrm{~A}$ ). Bu test ile ağrı oluşması, anterolateral kalça patolojilerini ve olası bir priformis sendromunu akla getirmelidir. Lateral rim sıkışma testinde ise, kalça eklemi pasif olarak abduksiyon ve dış rotasyona getirilir (Şekil 25 B). Ağrı mevcudiyetinde posterior sıkışma ya da anterior kalça instabilitesi düşünülmelidir. Eğer hasta huzursuzluk ile birlikte kalça ekleminde öne hareketlilik ve anterior kalça ağrısı tanımlıyorsa, bu durum anterior instabilite ile ilişkilendirilebilir.

Lateral bacak kaldırma ve Ober testleri, kalçanın abduktor adaleleri ve iliotibial bant problemleri ile ilgili değerlendirme yapma olanağı sunar. Lateral bacak kaldırma sırasında hastanın özellikle trokanter majör ve civarında ağrı tanımlaması, abduktor tendinit, trokanterik bursit, iliotibial bant kontraktürü ve tendinitlerini 

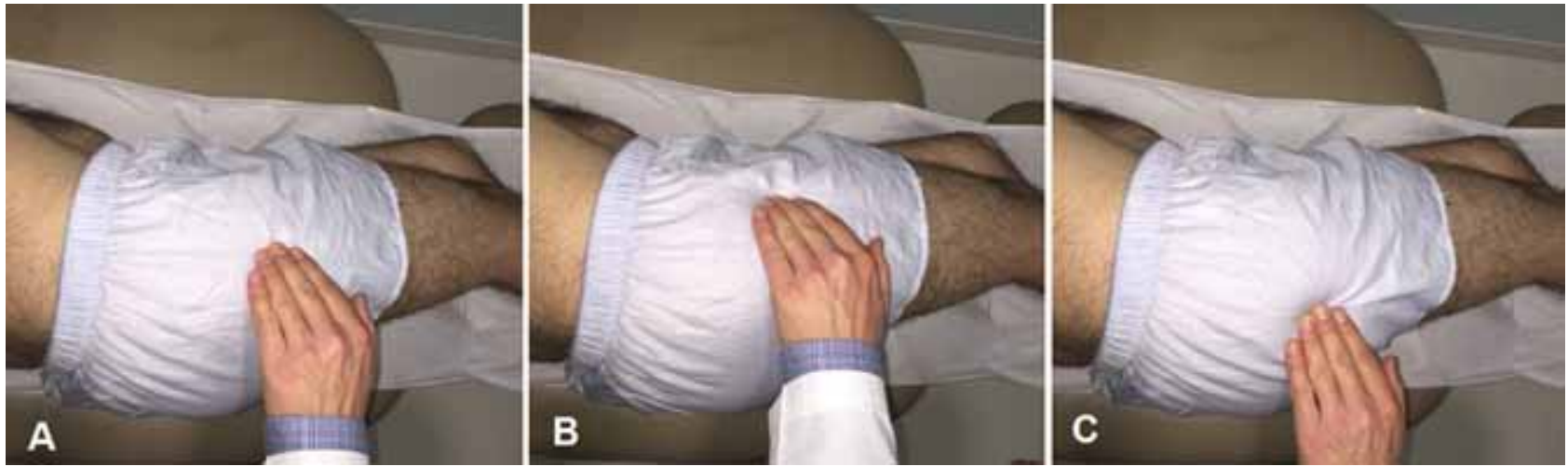

Şekil 24. A-C. Trokanter majörün palpasyonu (A). Trokanter majörün anteriorunun palpasyonu (B). Trokanter majörün posteriorunun palpasyonu (C).

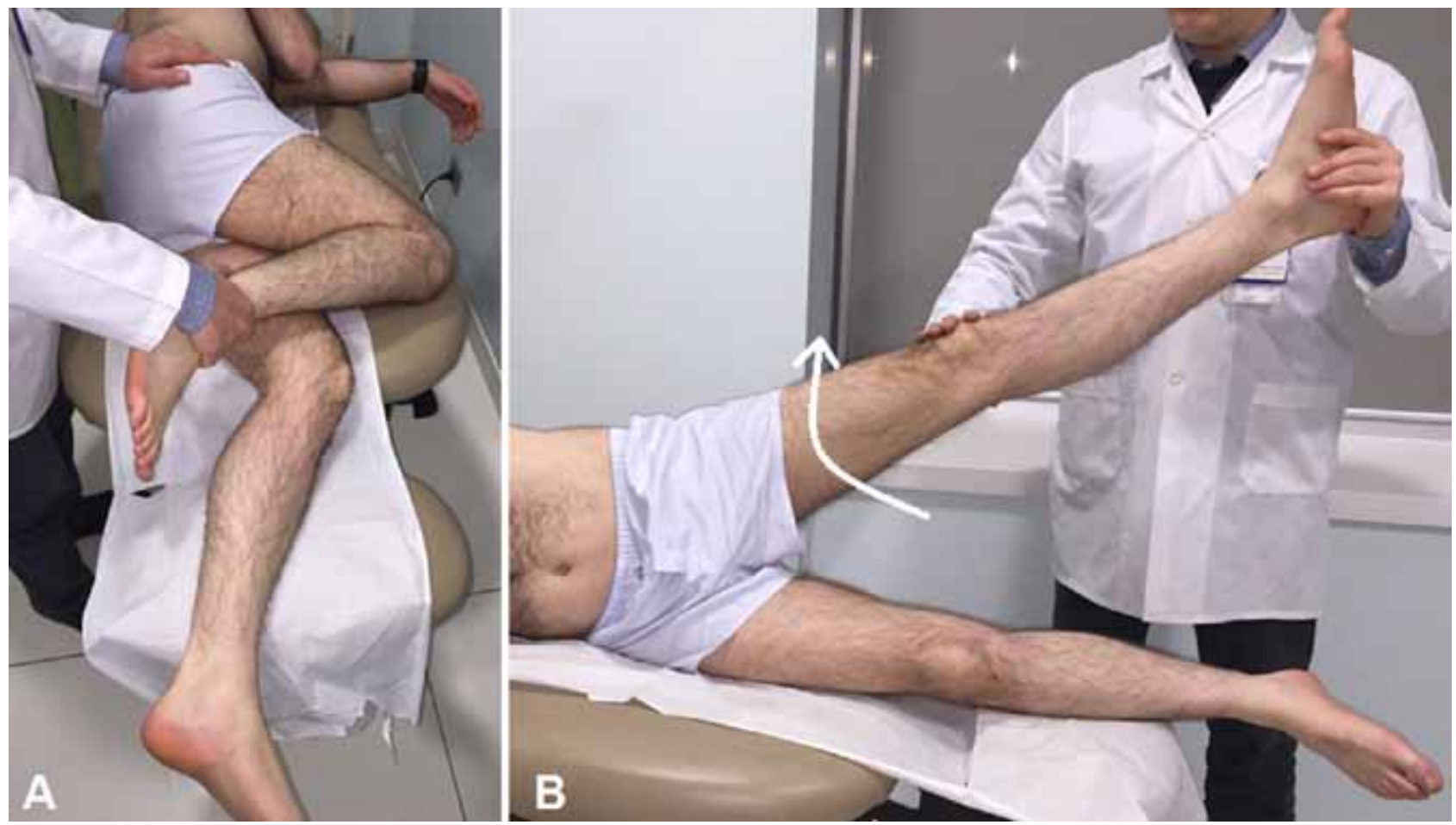

Şekil 25. A, B. Lateral dekübit pozisyonda FADIR testi (A). Lateral rim sıkışma testi (B).

akla getirmelidir. Ober testinde ise, özellikle iliotibial bant ve abduktor adalelerdeki kontraktür varlığı araştırılır. Ober testinde, lateral dekübit pozisyonda kalça abduksiyona alınır. Kalçanın, bırakıldığında yer çekiminin etkisi ile aşağıya düşüp düşmediğine bakılır. Test sırasında diz ve kalça eklemlerinin pozisyonuna göre farklı yorumlar yapılabilir. Eğer diz ve kalça ekstansiyonda iken abduktor gerginlik varsa, patolojinin iliotibial bant ve tensor fasya lata ile ilişkili olacağı düşünülür. Eğer kalça eklemi nötralde iken diz fleksiyonuna rağmen abduktor gerginlik oluşmuşsa, gluteus mediusa ait bir kontraktür ya da spastisite akla getirilir. Aynı taraf omuz eklemi ters yöne çevrilerek, diz ekstansiyonda ve kalça eklemi fleksiyonda iken abduktor gerginlik mevcutsa, gluteus maksimus gerginliği düşünülmelidir (Şekil 26).

Daha önce bahsedilen kütleyen kalça patolojisinin eksternal nedeni olan iliotibial bant snapping'i, lateral dekübit pozisyonda değerlendirilmelidir. Bu pozisyonda yatarken hafif adduksiyona alınmış kalça eklemi, fleksiyon ve ekstansiyon yönünde hareket ettirilir. Bu esnada, trokanter majör üzerinde iliotibial bantın atlaması palpasyonla hissedilebilir, hatta bazen de görülebilir (Şekil 27). 

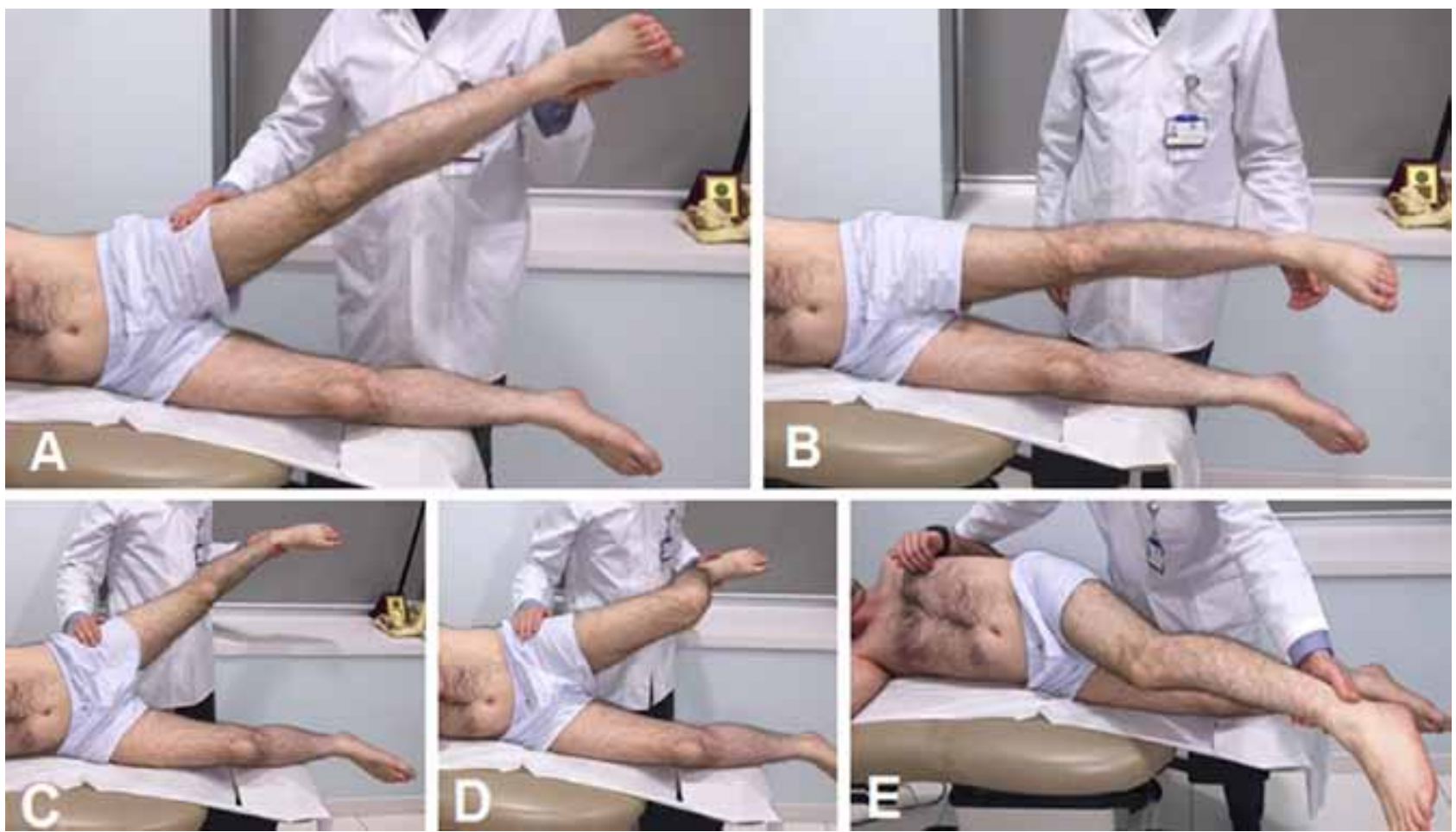

Şekil 26. A-E. Lateral bacak kaldırma testi (A). Ober testinde abduktor gerginlik nedeniyle alt ekstremitenin yer çekimi etkisine rağmen masa düzlemine yaklaşmaması (B). Kalça ve diz eklemi ekstansiyonda iken abduktor gerginliğin gözlenmesi (C). Kalça eklemi nötralde, diz eklemi fleksiyonda iken abduktor gerginliğin oluşması (D). Omuz eklemi ters yöne çevrilerek kalça eklemi fleksiyonda ve diz eklemi ekstansiyonda abduktor gerginliğin gözlenmesi (E).
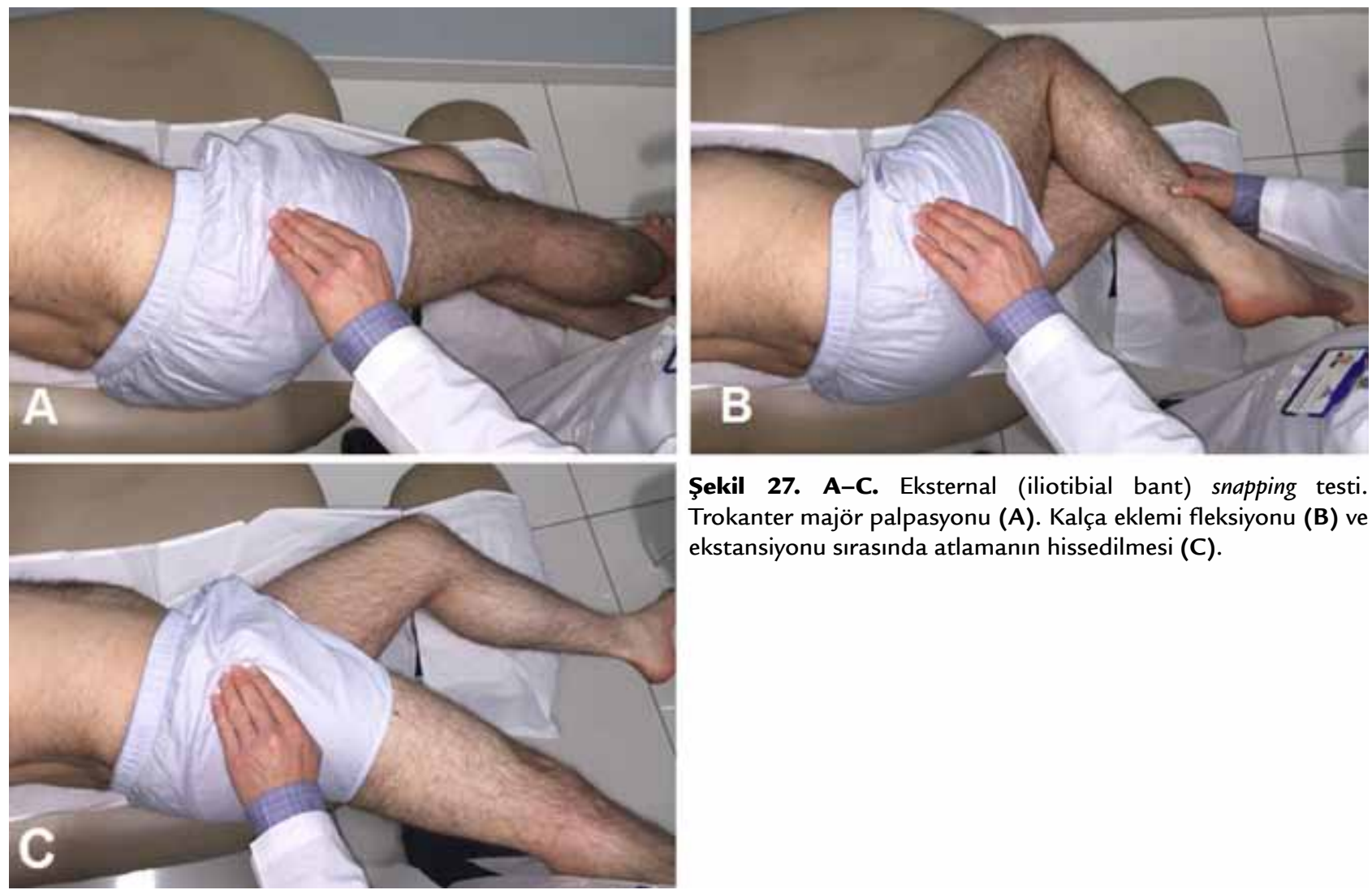

Şekil 27. A-C. Eksternal (iliotibial bant) snapping testi. Trokanter majör palpasyonu (A). Kalça eklemi fleksiyonu (B) ve ekstansiyonu sırasında atlamanın hissedilmesi (C). 

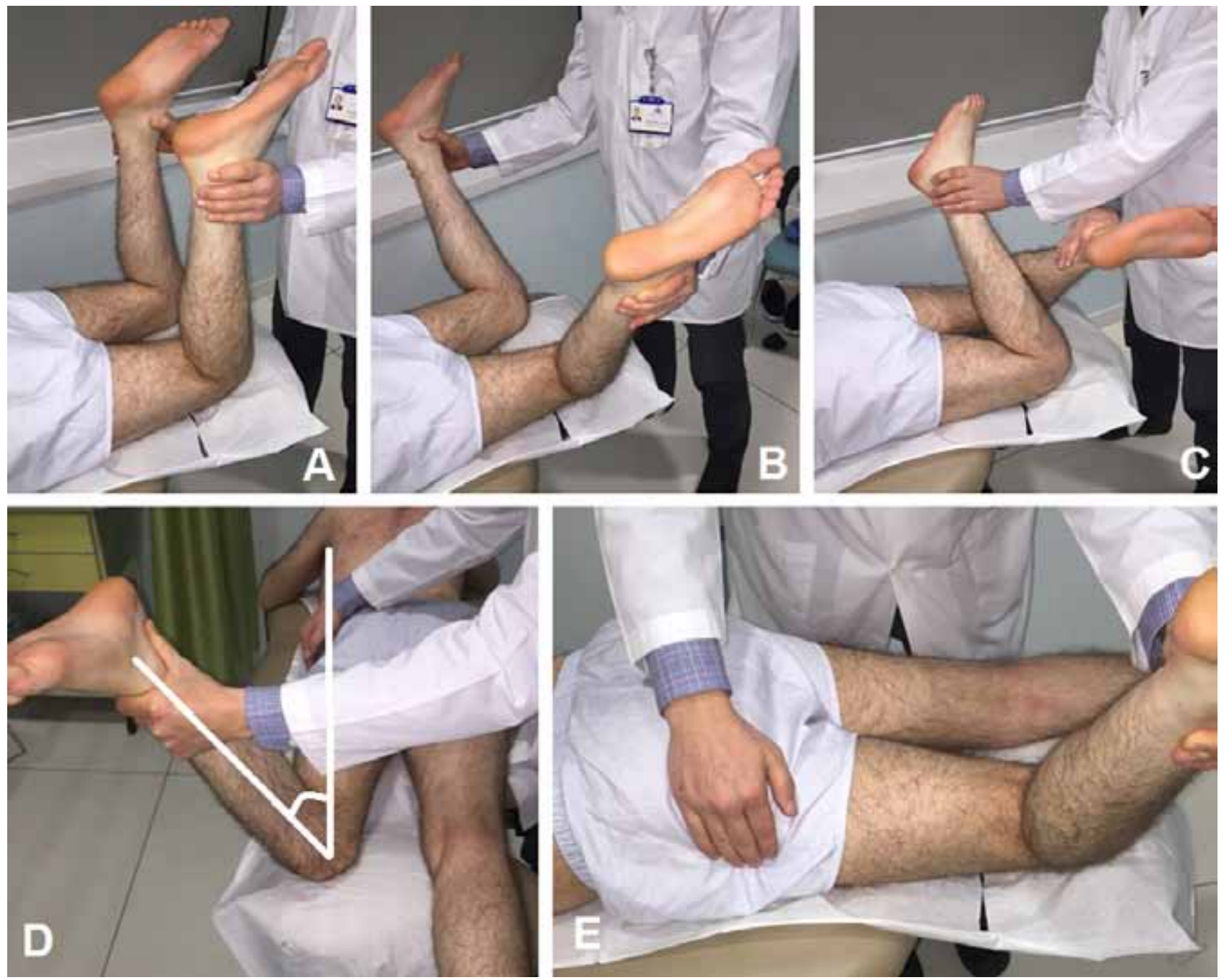

Şekil 28. A-E. Prone pozisyonda kalça eklemi iç ve dış rotasyonunun gözlenmesi (A-C). Femoral anteversiyon değerlendirmesi (Craig testi) (D, E).

\section{YATARKEN FIZIK MUAYENE (PRONE POZISYON)}

Kalça muayenesine, yüzükoyun (prone) pozisyonda bakılacak fizik muayene yöntemleri ile devam edilmelidir. Öncelikle, bu pozisyonda yatan bir hastada kalça iç ve dış rotasyonu değerlendirilir; bu şekilde, her iki kalça ekleminin de simetrik olarak değerlendirilebilme olanağı vardır (Şekil 28 A-C). Ardından, her iki kalçada femoral anteversiyonlar gözlemlenir (Craig testi). Bu testte, diz eklemi $90^{\circ}$ fleksiyonda iken kalça eklemi lateralinde trokanter majör palpe edilir. Kalça eklemi iç rotasyona çevrilmeye başlanır ve trokanter majörün en lateralde palpe edilebildiği noktada iç rotasyon sonlandırılır. Muayene masasına vertikal uzanan aks ile krurisin longitudinal aksı arasındaki açı değeri, femoral anteversiyonu gösterir (Şekil $28 \mathrm{D}$ ve E). Test mutlaka kıyaslamalı değerlendirilmelidir.
Ely testi, yüzükoyun pozisyonda rektus femorise ait spastisite ya da kontraktürleri değerlendirmeye yardımcı bir testtir. Yüzükoyun pozisyonda yatan hastada diz eklemi fleksiyona getirildiğinde, normalde dizin büküldügü tarafta pelvis muayene masasıyla olan ilişkisi kaybetmez. Eğer kalça ekleminde rektus femorise ait bir gerginlik söz konusu ise, diz fleksiyonu ile pelvis muayene düzleminden yukarıya doğru havalanmaya başlar (Şekil 29). Bu durum, gergin rektus femorisin yapıştığı yerden (spina iliaka anterior inferior - SiAi) pelvisi anteriora doğru döndürmesi ve gluteal bölgeyi havalandırması sonucu oluşur.

Son olarak, yüzükoyun pozisyonda nadir de olsa kalça ağrısı yaratabilecek, L2-L3 sinir kökü sıkışmalarını ve radikülopatilerini ortaya çıkarabilecek, femoral sinir germe testine de bakılmalıdır. 

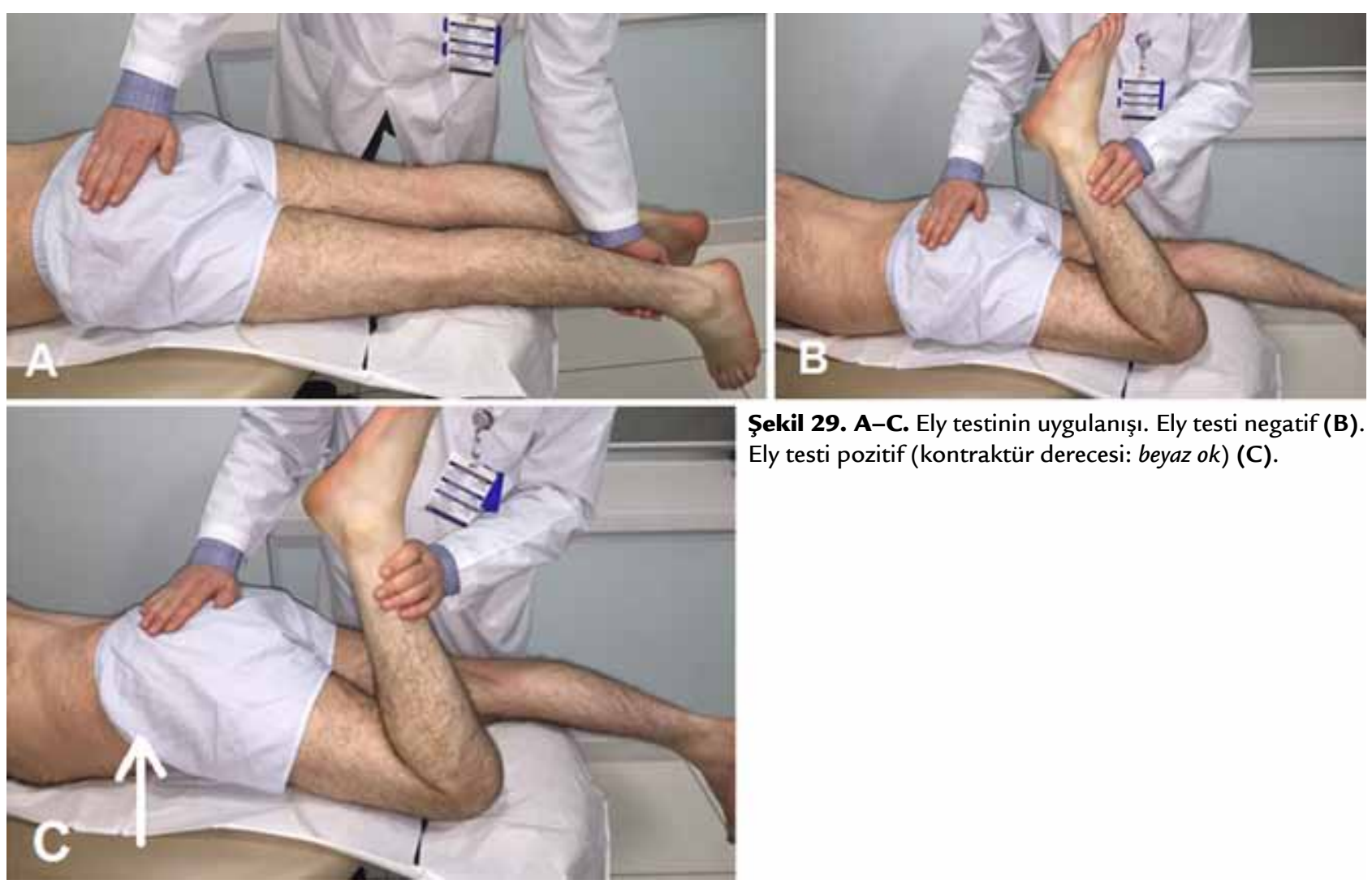

Şekil 29. A-C. Ely testinin uygulanışı. Ely testi negatif(B). Ely testi pozitif (kontraktür derecesi: beyaz ok) (C).

\section{KALÇA EKLEMINDE RADYOLOJiK DEĞERLENDIRME}

Genç erişkin ve erişkin hastalarda kalça ağrısının nedenleri arasında çok sayıda farklı eklem içi ve dışı patoloji yer alabilir. Gelişimsel kalça displazisi (GKD) ve FAS, bu patolojiler içerisinde en sık rastlanan yapısal kalça problemleri olmakla birlikte, diğer olasılıklar da akılda tutulmalıdır. Ayrıntılı klinik öykü sorgusu ve sistematik bir fizik muayene uygulaması ardından, kalça ve pelvise ilişkin radyolojik tetkiklerle tanıya yönelmek mümkündür.

Radyolojik değerlendirmedeki temel amaç, yapısal anatomiyi ve ilişkili anormallikleri saptamak, eklem aralığını değerlendirmek ve femoroasetabular eklem uyumluluğunu ortaya koymaktır. Düz radyografiler, manyetik rezonans (MR) görüntüleme, artro $M R$ ve bilgisayarlı tomografi (BT), pelvis ve kalça eklemine yönelik sık kullanılan görüntüleme tetkikleridir. Yazının devam eden bölümlerinde, bu tetkikler içerisinde en sık kullandığımı düz radyografiler hakkında bilgi verilmeye çalışılacaktır.

ANCHOR (Academic Network for Conservational Hip Outcomes Research) grubunun ${ }^{[6]}$ kalça ağrısı nedeniyle değerlendirilen hastalarda çekilmesini önerdiği standart radyografiler şunlardır:
- Pelvis ön-arka grafi.

- Cross-table lateral grafi.

- Dunn lateral grafi $\left(45^{\circ}\right.$ ve $\left.90^{\circ}\right)$.

- Pelvis frog-leg grafi.

- False-profile grafi.

\section{Pelvis ön-arka grafi}

Hasta sırtüstü yatar pozisyondayken, her iki kalça eklemi $15^{\circ}$ iç rotasyona getirilerek (femur boyun uzunluğunu net görebilmek için) çekilen ön-arka grafidir. Röntgen tüpü masadan yaklaşık $120 \mathrm{~cm}$ uzaklıkta olmalıdır ve simpifiz pubis ile her iki SiAS'ı birleştiren çizginin tam ortasına hizalanmalıdır. Çekilmiş olan grafide, iliak kanatlar, obturator foramenler ve gözyaşı figürleri simetrik gözükmelidir. Ayrıca, koksiks de simfizis pubis ile aynı hizada görülmelidir.

Pelvis ön-arka grafide, GKD ve FAS sendromuna ilişkin birçok radyografik bulgu ortaya koyulabilir. Femur başının asetabulum tarafından örtümü ve femoroasetabular uyumluluk değerlendirilebilir. Ayrıca femur başı sferisitesi yorumlanabilir. Eklem aralığı mesafeleri her iki kalça arasında kıyaslanabilir. Asetabular inklinasyon ve versiyon değerlendirmeleri yapılabilir. 


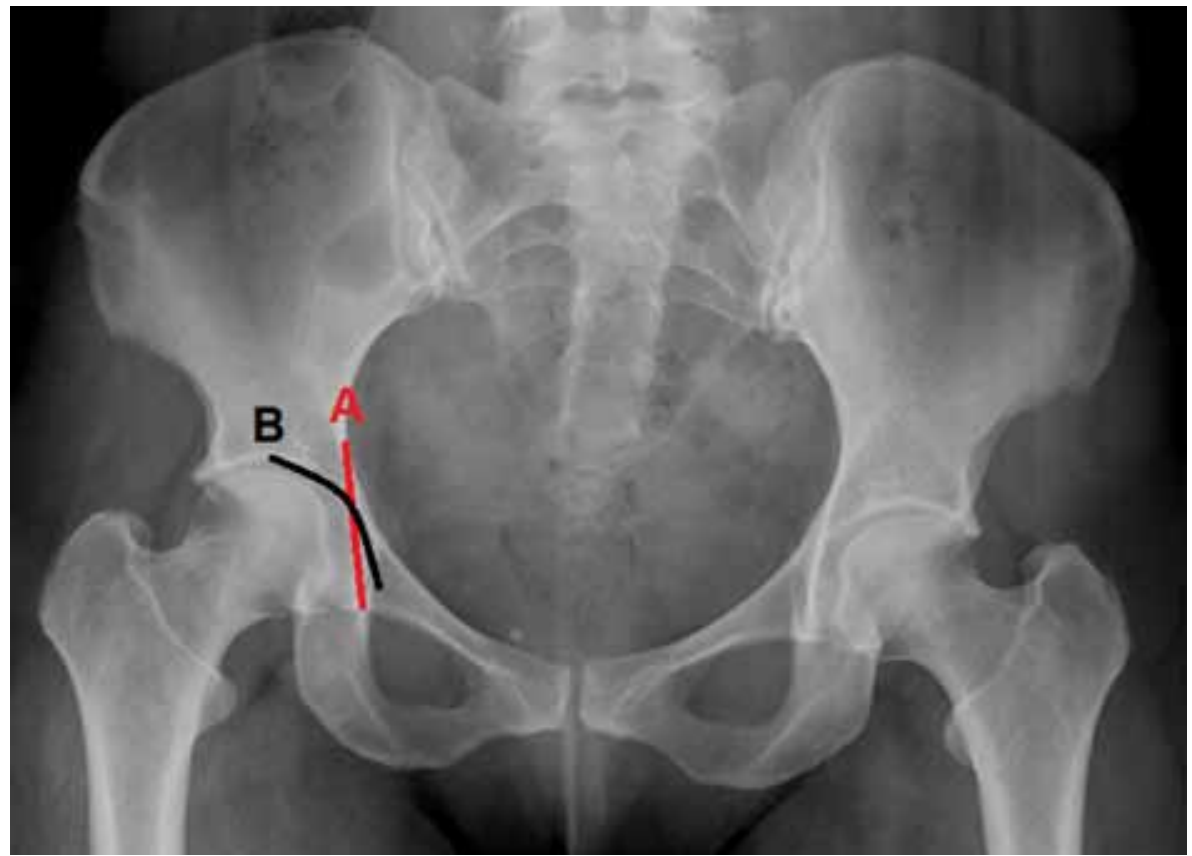

Şekil 30. Ön-arka pelvis radyografisinde asetabular derinlik değerlendirmesi. Grafide asetabular fossa tabanının (siyah çizgi, B) ilioiskial hattın (kırmızı çizgi, A) mediyalinde yer aldığı koksa profunda örneği görülmekte.

\section{Cross-table lateral grafi}

Sırtüstü yatan hastada, değerlendirilmeyecek kalça $90^{\circ}$ fleksiyona alınarak görüntüleme alanından uzaklaştırılır. Değerlendirilecek kalça $15^{\circ}$ iç rotasyona getirilir ve röntgen tüpü $45^{\circ}$ açıda femur başını ortalayacak şekilde, lateral planda görüntü alınır. Bu grafi ile femur başının anterolaterali görüntülenmeye çalışılır.

\section{$45^{\circ}$ ve $90^{\circ}$ Dunn lateral grafiler}

Sırtüstü yatan ve kalçasını nötral rotasyon, $20^{\circ}$ abduksiyon pozisyonunda tutan hastada sırasıyla, $45^{\circ}$ ve $90^{\circ}$ kalça fleksiyonlarında ön-arka pozisyonda görüntüler alınır. Röntgen tüpü pelvis ön-arka grafisinde olduğu gibi masaya dik konumlanır ve masa ile arasında yaklaşık 102 cm'lik bir mesafe vardır.

\section{Pelvis frog-leg grafi}

Supin pozisyonda yatan hastada, kalça eklemi $45^{\circ}$ abduksiyona ve dizler $30^{\circ}-40^{\circ}$ fleksiyona getirilerek, kurbağa bacağı pozisyonunda görüntüleme yapılır. Röntgen tüpü uzaklığı 102 cm'dir.

\section{False-profile grafi}

Ayakta çekilen bir grafidir. Hastanın etkilenen kalçası röntgen tüpüne $65^{\circ}$ açı ile yaklaşır. Röntgen tüpü femur başını merkeze alacak şekilde ayarlanır ve kasete dik açı ile grafı çekilir. Görüntülenen ekstremitede ayak, röntgen kasetine paralel durmalıdır. Tüp kasete yaklaşık $102 \mathrm{~cm}$ uzaklıktadır.

Ön-arka pelvis grafisi dışındaki tüm grafilerde, femur başı ve asetabuluma ait lateral plan görüntüleri elde edilir. Pelvis ön-arka ve false-profile grafilerde sıkIıkla asetabulum morfolojisi ve asetabular patolojilerle ilgili değerlendirmeler yapılırken, lateral grafiler olarak adlandırılan cross-table, Dunn ve frog-leg grafilerde proksimal femur anatomisindeki değişiklikler gözlemlenebilmektedir. Özellikle femur baş-boyun bileşkesinin anterior, anterolateral ve anterosuperiorundaki deformiteler, bu grafiler ile net olarak izlenebilir. Lateral grafilerde ayrıca, anterior ve posterior eklem aralıkları ile asetabular dudaklar (rim) da değerlendirilebilir.

\section{RADYOGRAFILERDE NELER DEĞERLENDIRILMELIDIR?}

\section{Asetabular derinlik}

Asetabular derinlik hakkında yorum yapabilmek için, ön-arka pelvis radyografisinde fossa asetabuli tabanı, femur başı mediyali ve ilioiskial hat ilişkilerinin değerlendirilmesi gerekir (Şekil 30). Asetabular fossa tabanı ilioiskial hat üzerinde ya da onun mediyalinde yer alıyorsa, koksa profunda tanımlaması kullanılmalıdır. Eğer femur başı mediyali ilioiskial hattın mediyalinde yer alıyorsa, o zaman da protrüzyo asetabuli tanımlaması yapılır. Her iki kalça tipinde de asetabular derinlik artmıştır. 


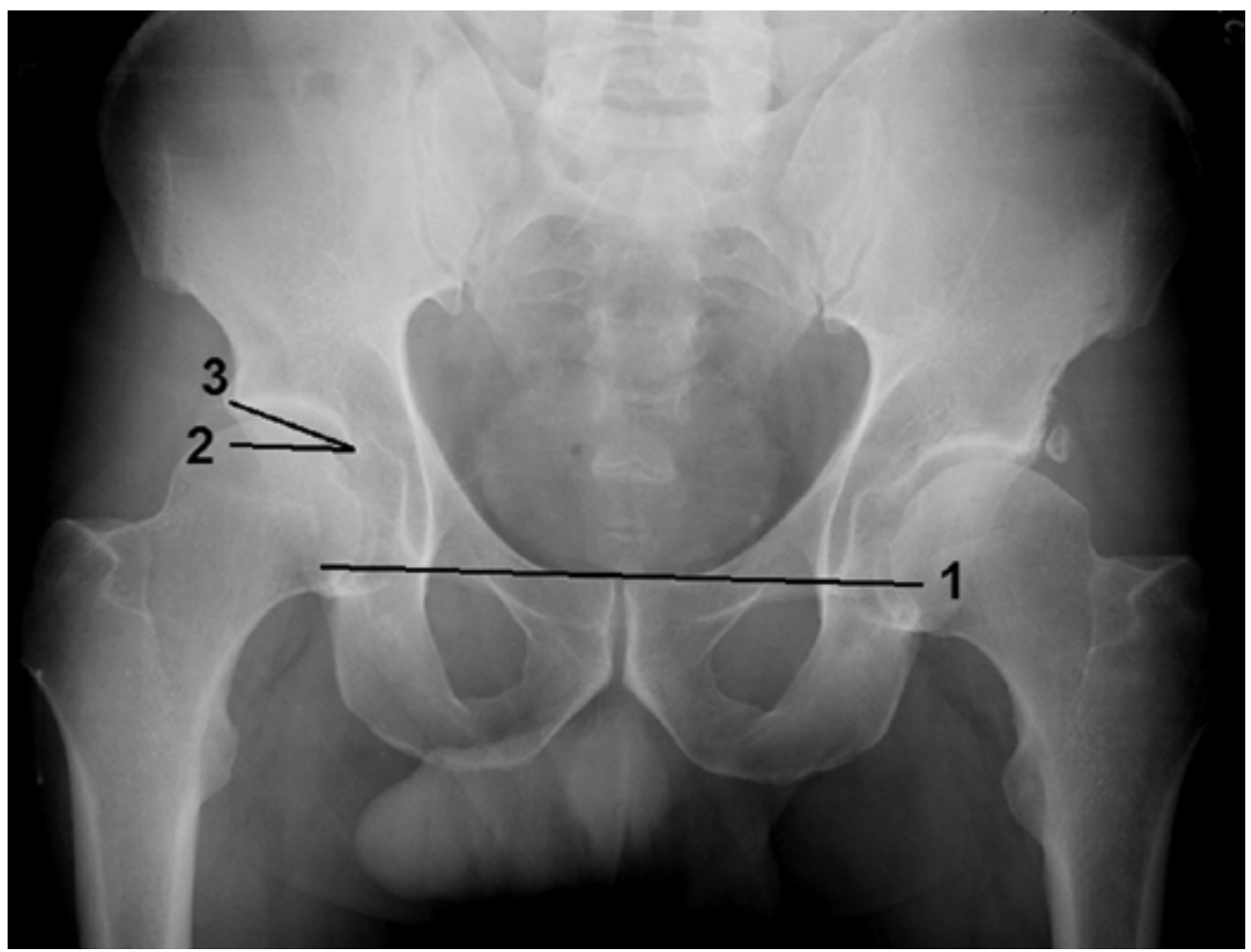

Şekil 31. Asetabular inklinasyon değerlendirmesi için Tönnis açısının ölçümü. 1 numaralı çizgi gözyaşı figürlerini birleştiren çizgidir. " 2 " numaralı çizgi asetabular skleroz hattının (sourcil'in) alt ucundan "1" numaralı çizgiye paralel olarak çizilir. "3" numaralı çizgi skleroz hattının (sourcil'in) üst ucundan alt ucuna doğru uzanır. " 2 " ve " 3 " numaralı çizgiler arası açı Tönnis açısıdır.

\section{Asetabular inklinasyon}

Asetabular indeks açısı, erişkin hastalarda Tönnis açısı ile değerlendirilir. Pelvis ön-arka radyografisinde, ilk önce gözyaşı figürlerini birleştiren yatay bir çizgi çizilir. Ardından, bu çizgiye paralel olacak şekilde, asetabulumun superolateralinde yer alan sklerotik hattın (sourcil) en alt ucundan geçen bir çizgi çizilir. Sourcil'in lateral üst ucundan alt ucuna uzanan ikinci bir çizgi çizilerek, alt uçtan geçen çizgi ile arasındaki açı ölçülür (Şekil 31). Açısal değerler $0^{\circ}-10^{\circ}$ arasında ise normaldir; eğer $>10^{\circ}$ ise artmış inklinasyon olduğu ifade edilir ve yapısal instabilite ile ilişkilendirilir. Açısal değerler $<0^{\circ}$ ise inklinasyonun azaldığını gösterir ve pincer tipi FAS ile birliktelik gösterebilir.

\section{Asetabular örtüm}

Asetabular örtüm, ön-arka ve false-profile pelvis grafilerinde değerlendirilir. Bu amaçla, lateral merkezkenar açısı (Wiberg) ve anterior merkez-kenar açısı (Lequesne) olarak adlandırılan iki açı ölçümü yapılır. Lateral merkez-kenar açısı, ön-arka pelvis grafisinde ölçülen ve femur başının asetabulum tarafından superolateral örtünme derecesini belirleyen, femur başı merkezinden pelvisin transvers eksenine dik olarak çizilen hat ile femur başı merkezinden sourcil'in superolateral köşesine çizilen hat arasındaki açıdır (Şekil $32 \mathrm{~A}$ ). $\mathrm{Bu}$ açı $25^{\circ}$ 'nin altında ise, femur başı örtümü yetersiz olarak kabul edilir.

Anterior merkez-kenar açısı ise false-profile grafide ölçülür. Femur başı merkezinden vertikal olarak uzanan hat ile femur başı merkezinden sourcil'in en anterior ucuna çizilen hat arasındaki açıdır (Şekil 32 B). Bu açı $20^{\circ}$ 'nin altında ise, femur başının anterior örtüm yetersizliğinden bahsedilir.

\section{Asetabular versiyon}

Ön-arka pelvis grafisinde asetabulumun versiyonu belirlenebilir ve buna göre antevert ya da retrovert olarak tanımlanabilir. Bunun için sıklıkla değerlendirilen radyografik parametreler, "Crossover" ya da "8 figürü" bulgularıdır. Ön-arka radyografide anterior ve posterior asetabular duvar ya da dudak çizgileri sourcil'in superolateral noktasında kesişiyorsa asetabulum antevert (Şekil $33 \mathrm{~A}$ ), eğer bu iki çizgi sourcil'in superolateral noktasına ulaşmadan önce kesişiyorsa asetabulum retrovert olarak kabul edilir (Şekil 33 B). Film kalitesi 

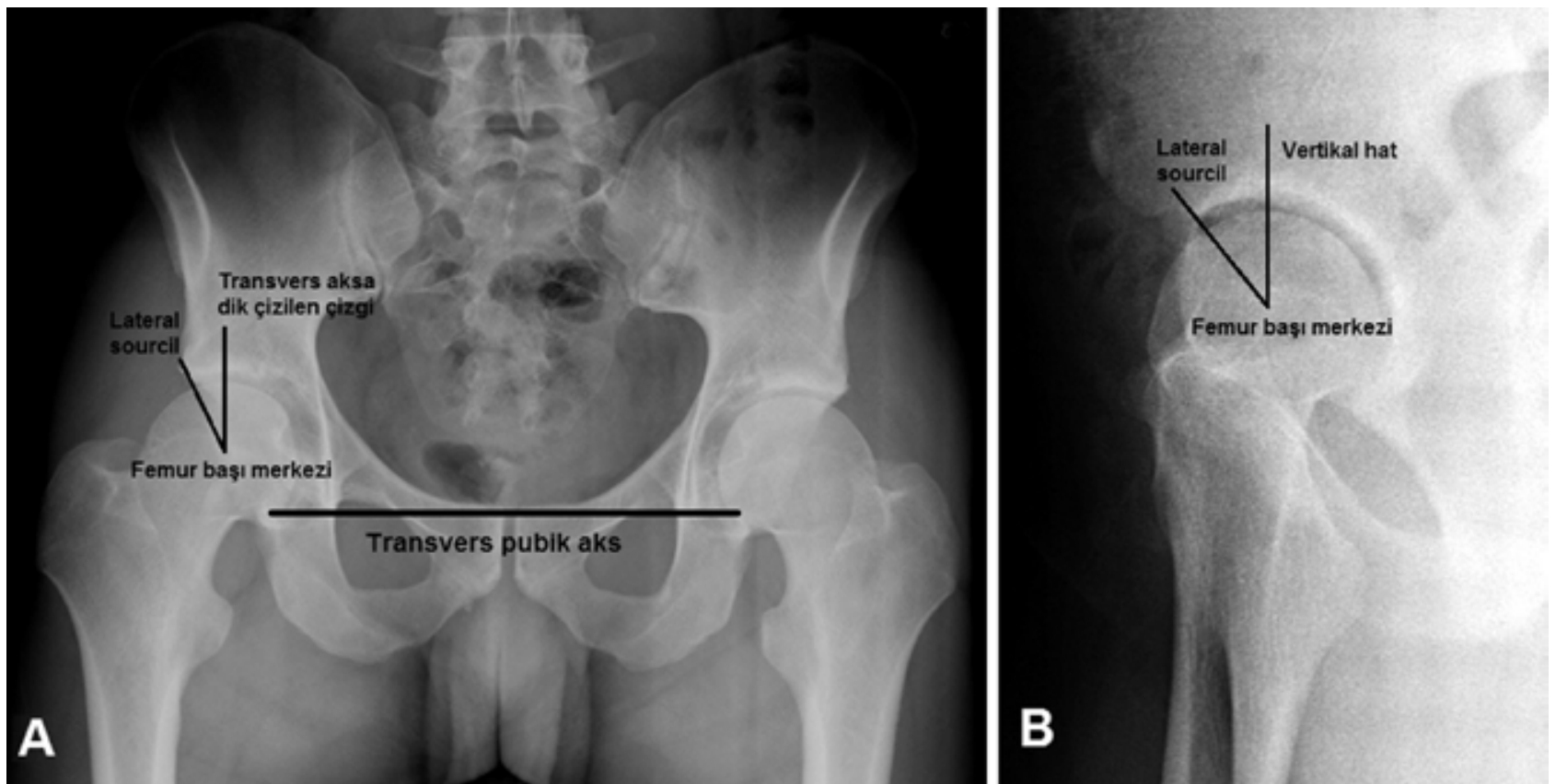

Şekil 32. A, B. Lateral merkez-kenar açısı (Weiberg) ölçümü (A). Anterior merkez-kenar açısı (Lequesne) ölçümü (B).
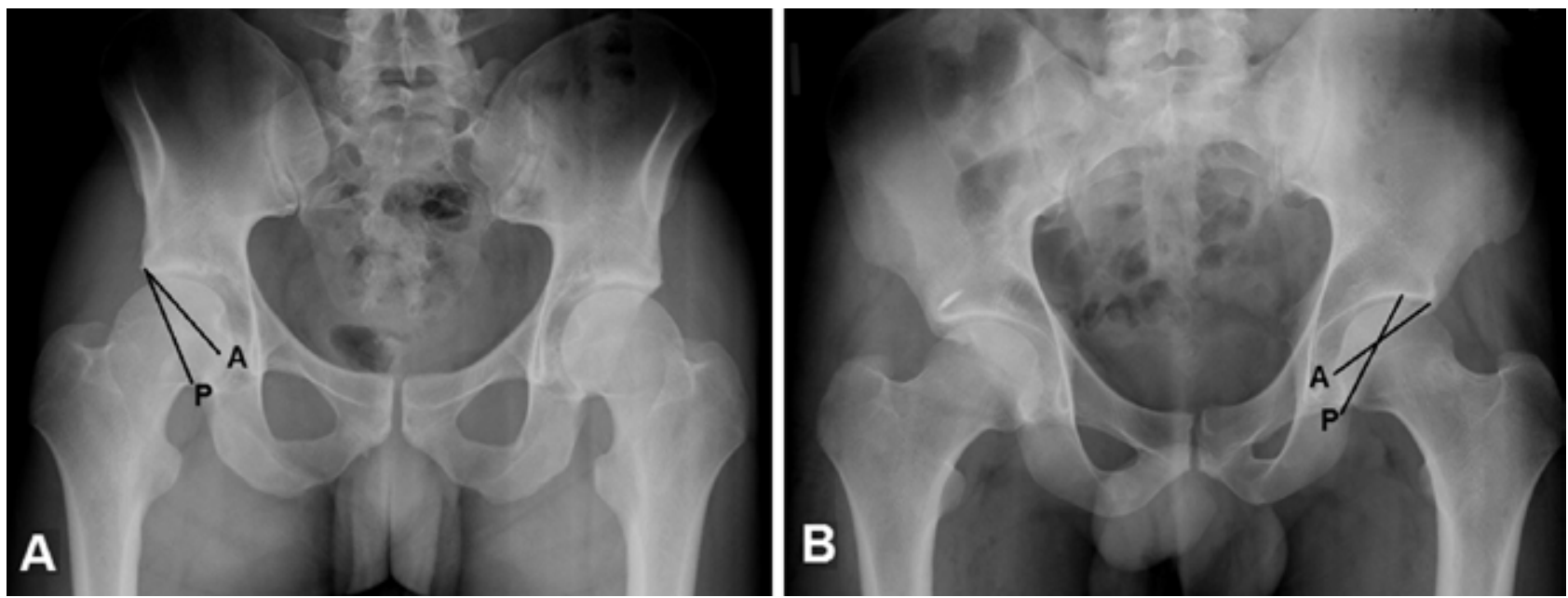

Şekil 33. A, B. Anterior $(\boldsymbol{A})$ ve posterior $(\boldsymbol{P})$ duvar çizgilerinin sourcil'in superolateral noktasında kesiştiği antevert asetabulum grafisi (A). Anterior $(\boldsymbol{A})$ ve posterior $(\boldsymbol{P})$ duvar çizgilerinin sourcil'in asetabulum ortasında kesiştiği retrovert asetabulum grafisi (B).

yeterli olmadığında ya da pelvik tilt ve rotasyon varlığında, anterior ve posterior dudak çizgilerini belirlemek zor olabilir. Böyle bir durumda, posterior dudak çizgisinin inferior uzanımını iskionla birleşme yerinde belirlemek kolaylık sağlayabilir ve anterior ve posterior çizgiler ayırt edilebilir. Ayrıca, iskial çıkıntının pelvis içerisinde belirgin olarak gözlenmesi (iskial çıkıntı prominensi) de asetabular retroversiyon bulgusu olarak ifade edilmektedir. Gerçek asetabular retroversiyonda, posterior duvarda örtüm yetersizliği söz konusudur. Anterior örtüm fazlalığında da "crossover" bulgusu gözlenebilir. Ancak, bu durumda posterior duvar örtüm yetersizliği yoktur. Posterior duvar yetmezliğine ise, femur başı merkezi ile posterior dudak çizgisi ilişkisine bakılarak karar verilir. Normalde, femur başı merkezi posterior dudak çizgisinin hemen üzerinde ya da bu çizginin mediyalindedir. Posterior duvar yetmezliğinde, femur başı merkezi asetabulumun posterior duvar çizgisinin lateralinde kalır.

\section{Femur başı sferisitesi}

Pelvis ön-arka, Dunn lateral, frog-leg ve cross-table lateral grafilerde, femur başı sferik ya da aseferik olarak 

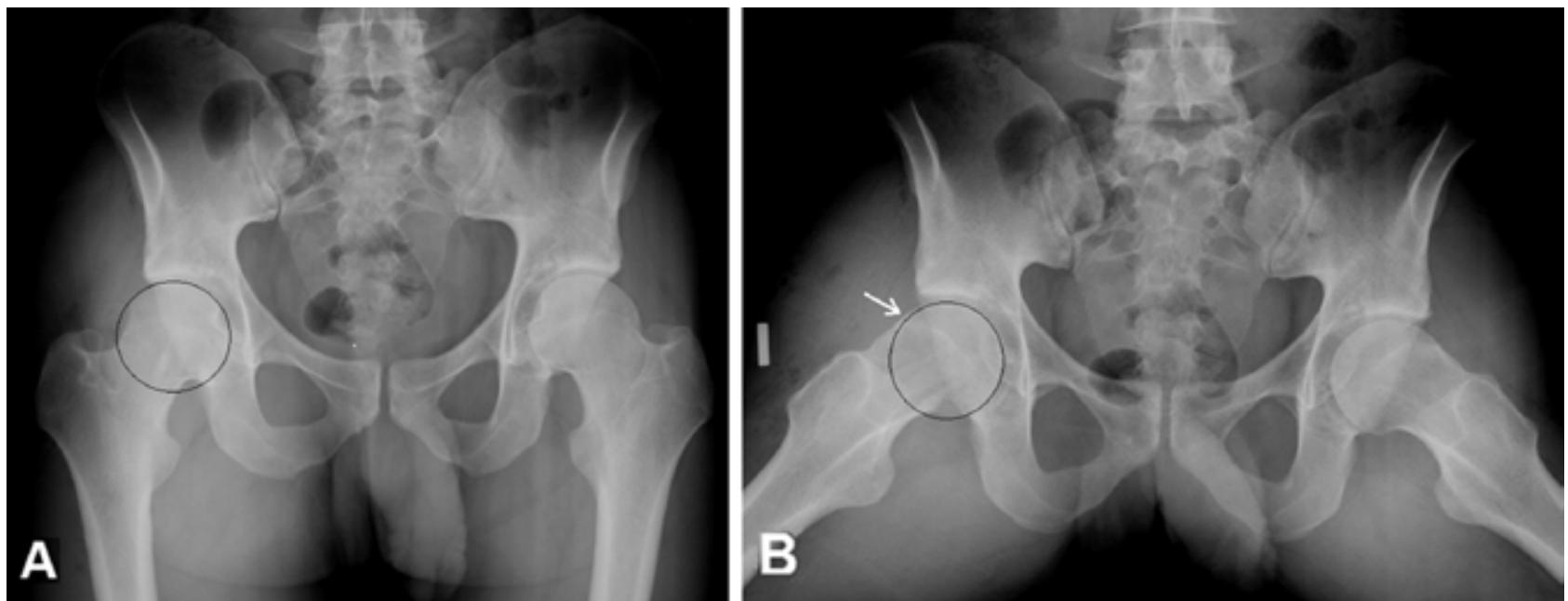

Şekil 34. A, B. Femur başı sferisitesinin değerlendirilmesi. Ön-arka pelvis radyografisinde femur başı sferisitesi gözlenmekte (A). Aynı hastanın frog-leg grafisinde femur baş-boyun bileşkesinin anterolateralinde sferikliği bozan taşma (beyaz ok) görülmekte (B).
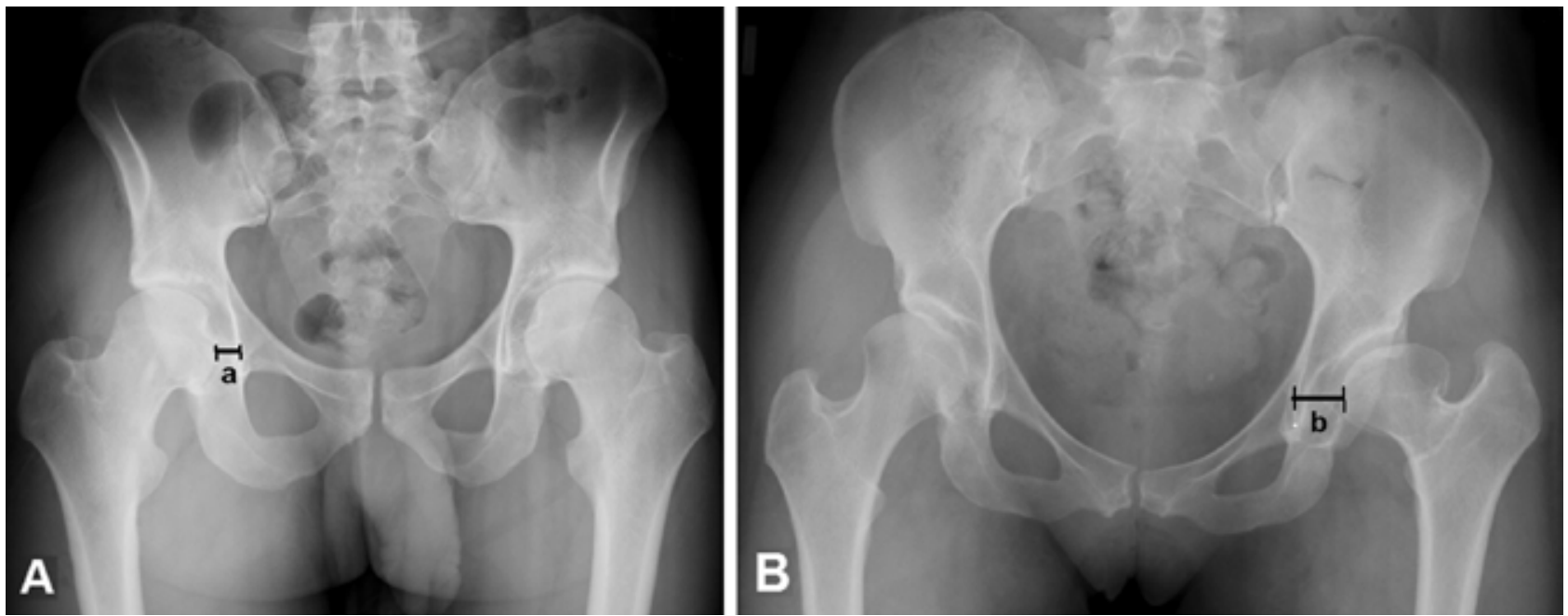

Şekil 35. A, B. Lateralize olmayan kalça $(a=7 \mathrm{~mm})(A)$. Lateralize kalça $(b=14 \mathrm{~mm})(B)$.

değerlendirilebilir. Genellikle gözlemsel değerlendirme, bu kararı vermek için yeterlidir. Ancak, Mose şablonu olarak bilinen konsantrik halka cetveli ile değerlendirme yapılabilir. Bu halkalarla değerlendirme yapılırken, uygun halka çapı belirlenir ve femur başına yerleştirilir. Femur başı, herhangi bir bölgeden halka çapını 2 mm'den daha fazla aşıyorsa, asferik olarak kabul edilir. Femur başı sferisitesini hem ön-arka, hem de lateral grafilerde ayrı ayrı değerlendirmek gerekir. Ön-arka grafilerde sferik olan femur başı, lateral grafilerde başboyun ofset deformitesi nedeniyle, asferik olarak değerlendirilebilir (Şekil 34).

\section{Kalça merkezinin pozisyonu}

Ön-arka pelvis radyografisi ile kalça merkezi pozisyonu değerlendirilebilir. Buna göre, lateralize olan ya da olmayan kalça tanımlamaları yapılabilir. Bu değerlendirme, femur başı mediyalinin ilioiskial hat ile ilişkisine bakılarak yapılır. Eğer femur başı mediyali iliosikial hattan $10 \mathrm{~mm}$ 'den daha fazla lateralde yer alıyorsa, lateralize kalça tanımlaması geçerlidir (Şekil 35).

\section{Baş-boyun kesişimi ve baş-boyun ofseti}

Dunn lateral, cross-table lateral ve frog-leg grafilerde, femur baş-boyun bileşkesinin anterior ve posteriorundaki kurvatur ve bunun simetrisi değerlendirilebilir. Eğer anterior ve posterior konkaviteler simetrikse, başboyun bileşkesi simetrik konkaviteye sahip kabul edilir. Eğer baş-boyun bileşkesinin anteriorundaki konkavite posteriorundakinden daha fazla bir radiusa sahipse, baş-boyun ofsetinde azalma söz konusudur. 

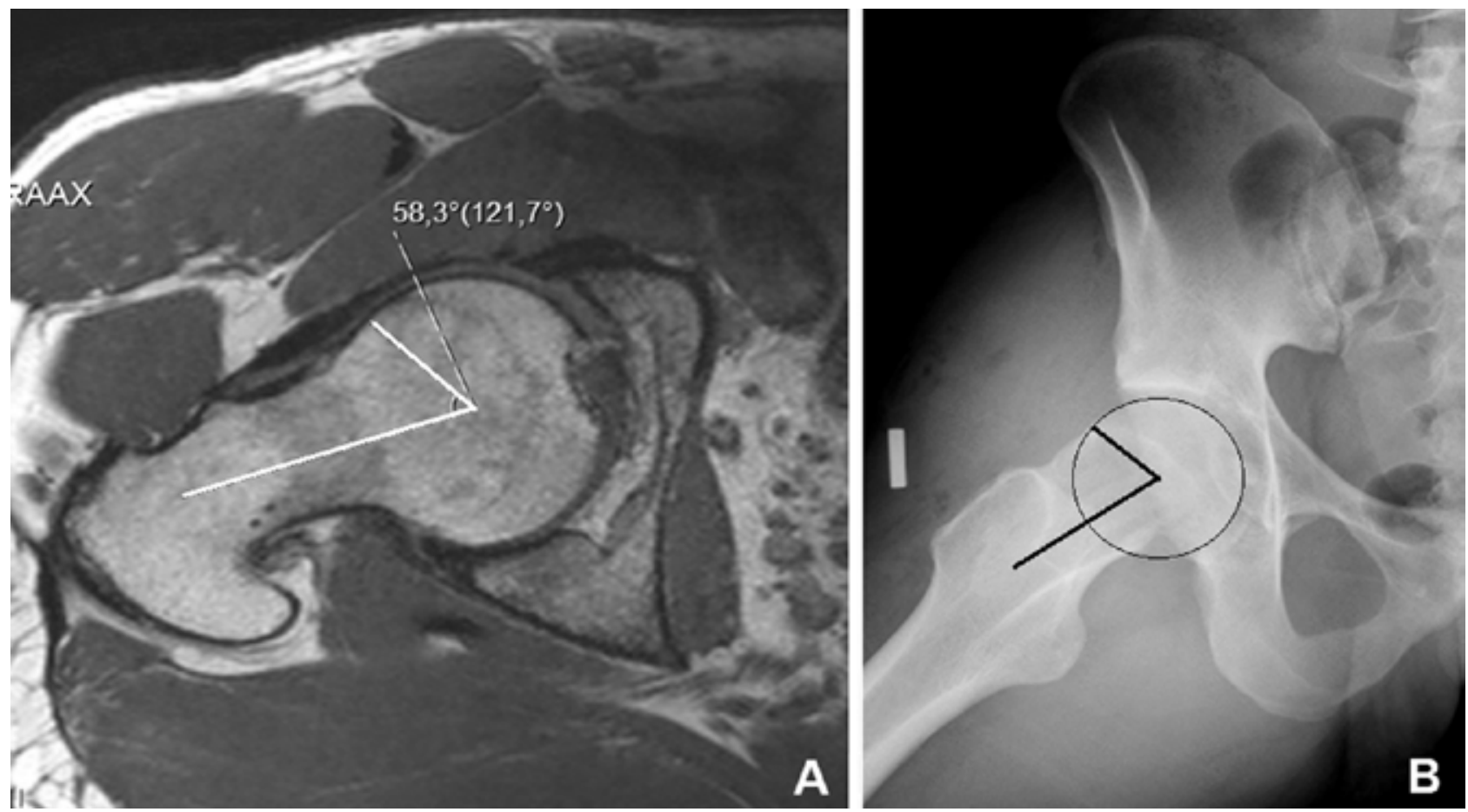

Şekil 36. A, B. Alfa açısının, aksiyel $M R$ kesitinde (A) ve lateral radyografide ölçümü (B).

Alfa açısı, baş-boyun ofseti hakkında yorum yapılmasını sağlayan bir açıdır; klasik olarak aksiyel MR kesitlerinde tanımlanmış olsa da, lateral radyografilerle de ölçülebilir. Bu açı, femur başı merkezinden geçen ve femur boynunu tam ortadan kesen hat ile femur başı merkezinden femur başı sferisitesinin bozulmuş olduğu noktaya, yani baş-boyun bileşkesinin anterolateralinde, femur başı çapının femur başının asetabulum ortasındaki çapından daha büyük olmaya başladığı noktaya çizilen hat arasındaki açıdır (Şekil 36). Açının $42^{\circ}$ 'den fazla olması, cam tipi FAS patolojisine işaret eder.

Alfa açısı dışında, baş-boyun ofset oranı hesaplaması da yapılabilir. Bunun için, birbirine paralel olarak çizilen üç çizgiden yararlanılır (Şekil 37). Birinci çizgi, femur boynunun uzun ekseninin ortasından çizilir. íkinci çizgi, bu çizgiye paralel olarak femur boynunun en anteriorundan teğet geçen çizgidir. Üçüncü çizgi ise, yine diğer çizgilere paralel olarak uzanan ve femur başının en anteriorundan teğet geçen çizgidir. Femur boynu ve başından geçen çizgiler (ikinci ve üçüncü çizgiler) arasındaki mesafe, femur başı çapına oranlanır. Oran 0,17 'den küçük ise, azalmış baş-boyun ofsetinden ve cam tipi FAS deformitesinden bahsedilebilir.

\section{Femoroasetabular uyumluluk}

Daha çok ön-arka pelvis grafilerinde değerlendirilen femur başı ve asetabulum ilişkisine göre, kalça

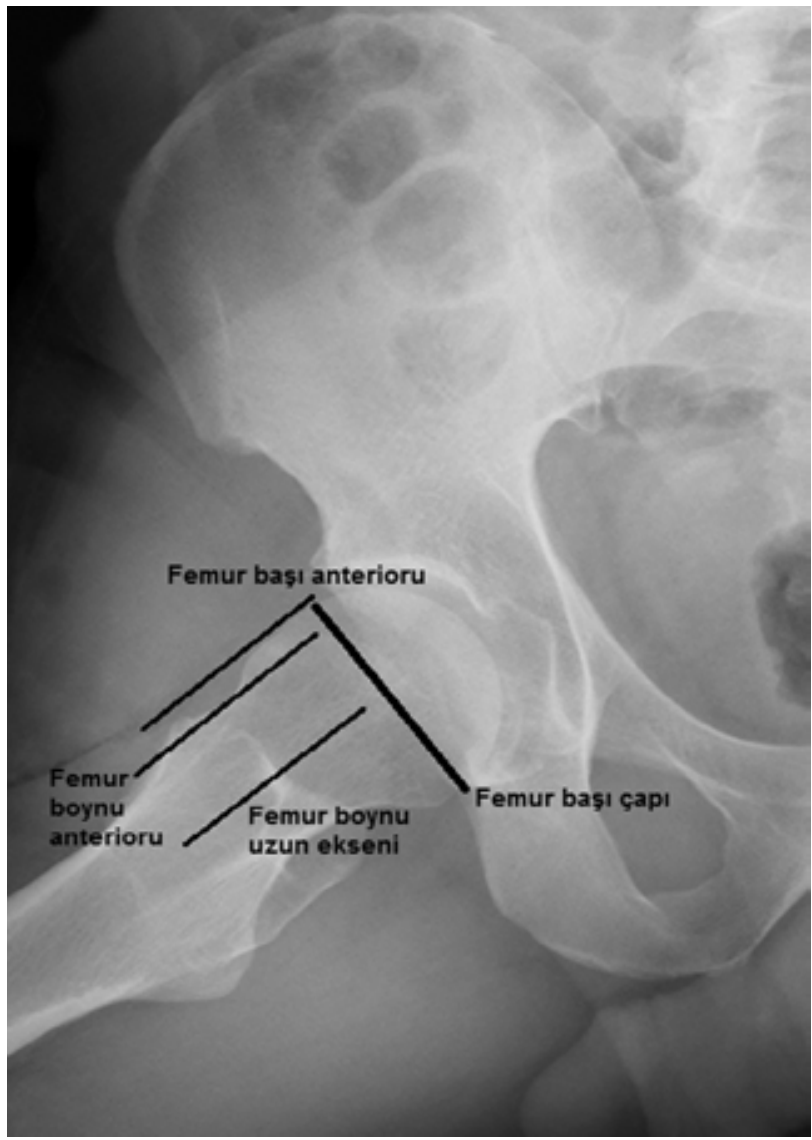

Şekil 37. Baş-boyun ofset oranı hesaplaması. Femur boynu anterioru ile femur başı anteriorundan teğet geçen çizgiler arasındaki mesafe femur başı çapına oranlanır. 
eklemleri uyumlu ya da uyumsuz olarak tanımlanabilir. Yasunaga ve arkadaşları ${ }^{[7]}$ uyumluluğu dört kategoride değerlendirmişlerdir (mükemmel, iyi, zayıf ve kötü). Uyumlu kalçalarda femur başı konveksitesi ya da yuvarlaklığı, asetabulumun konkavitesi ile tam olarak örtüşmektedir. Eğer bu örtüşme ya da paralellik bozulursa uyumsuzluktan bahsedilir. Diğer grafilerin aksine, false-profile grafilerde posterior eklem uyumluluğu da değerlendirilebilir.

\section{Tönnis evrelemesi}

Tönnis klasifikasyon sistemi ile her kalça sahip olduğu osteoartrit derecesine göre evrelendirilebilir. Buna göre; Evre 0, osteoartrit bulgularının olmadığı kalçaları; Evre 1, femur başı ve asetabulumda artmış sklerozun, eklem aralığında hafif derecede daralmanın ve eklem kenarlarında hafif osteofitik çıkıntıların ve belirginleşmelerin olduğu kalçaları; Evre 2, femur başı ya da asetabulumda küçük kistlerin oluştuğu, femur başı sferisitesinin orta düzeyde bozulduğu, orta düzeyde eklem aralığı daralmasının mevcut olduğu kalçaları; Evre 3 ise femur başı ve asetabulumda büyük kistlerin bulunduğu ve ileri derecede eklem aralığı daralması ile birlikte femur başı sferikliğinin kaybolup deforme olduğu ya da nekroz bulgularının görüldüğü kalçaları ifade eder.

Yukarıda tanımlanmaya çalışılan radyografiler ve değerlendirme yöntemleri dışında, kalça ağrısı tanımlayan hastalarda ileri görüntüleme tetkiklerine de başvurulabilir. Özellikle BT ile, pelvik halkanın üç planlı anatomisi ve ilişkili deformiteleri net bir şekilde ortaya koyulabilir. MR ve artro MR görüntüleme tetkikleriyle, labral ve kondral yüzeylerin bütünselliği, dejenerasyon ve yırtık varlığı gözlemlenebilir. Bu yöntemlere ilişkin ayrıntılı bilgiler bu makaleye dahil edilmemiştir.

\section{Teşekkür}

Klinik muayene görüntülerinin hazırlanmasında katkılarından dolayı Dr. Berhan Yıldırımkaya'ya teşekkürlerimizi sunarı.

\section{KAYNAKLAR}

1. Byrd JW, Jones KS. Hip arthroscopy in athletes. Clin Sports Med 2001;20(4):749-61.

2. Burnett RS, Della Rocca GJ, Prather H, Curry M, Maloney WJ, Clohisy JC. Clinical presentation of patients with tears of the acetabular labrum. J Bone Joint Surg Am 2006;88(7):1448-57.

3. Martin HD, Kelly BT, Leunig M, Philippon MJ, Clohisy JC, Martin RL, Sekiya JK, Pietrobon R, Mohtadi NG, Sampson TG, Safran MR. The pattern and technique in the clinical evaluation of the adult hip: the common physical examination tests of hip specialists. Arthroscopy 2010;26(2):161-72. CrossRef

4. Martin HD, Palmer IJ. History and physical examination of the hip: the basics. Curr Rev Musculoskelet Med 2013;6(3):21925. CrossRef

5. Mora SA, Mandelbaum BR, Szalai LJ, Potter ND, A, Ryan J, Meyers WC. Extraarticular Sources of Hip Pain. In: Thomas Byrd JW, editor. Operative hip arthroscopy, 2nd ed. New York, NY: Springer Science Business Media, Inc; 2005. p.78-83.

6. Clohisy JC, Carlisle JC, Beaulé PE, Kim YJ, Trousdale RT, Sierra RJ, Leunig M, Schoenecker PL, Millis MB. A systematic approach to the plain radiographic evaluation of the young adult hip. J Bone Joint Surg Am 2008;90 Suppl 4:47-66. CrossRef

7. Yasunaga Y, Ikuta Y, Kanazawa T, Takahashi K, Hisatome T. The state of the articular cartilage at the time of surgery as an indication for rotational acetabular osteotomy. J Bone Joint Surg Br 2001;83(7):1001-4. 